Sexual Selection for Moral Virtues

Review by: Geoffrey F. Miller

The Quarterly Review of Biology, Vol. 82, No. 2, Contents (June 2007), pp. 97-125

Published by: The University of Chicago Press

Stable URL: http://www.jstor.org/stable/10.1086/517857

Accessed: 29/05/2012 04:53

Your use of the JSTOR archive indicates your acceptance of the Terms \& Conditions of Use, available at http://www.jstor.org/page/info/about/policies/terms.jsp

JSTOR is a not-for-profit service that helps scholars, researchers, and students discover, use, and build upon a wide range of content in a trusted digital archive. We use information technology and tools to increase productivity and facilitate new forms of scholarship. For more information about JSTOR, please contact support@jstor.org. 


\title{
SEXUAL SELECTION FOR MORAL VIRTUES
}

\author{
Geoffrey F. Miller \\ Psychology Department, University of New Mexico \\ Albuquerque, New Mexico 87131 USA \\ E-MAIL: GFMILLER@UNM.EDU
}

KEYWORDS

agreeableness, alternative mating strategies, altruism, assortative mating, behavior genetics, commitment, conscientiousness, costly signaling theory, equilibrium selection, emotion, empathy, ethics, evolutionary psychology, fitness indicators, genetic correlations, good genes, good parents, good partners, human courtship, kin selection, kindness, individual differences, intelligence, mate choice, mental health, moral virtues, mutation load, mutual choice, person perception, personality, reciprocal altruism, sexual fidelity, sexual selection, social cognition, virtue ethics

"Human good turns out to be the activity of the soul exhibiting excellence." Aristotle (350 BC)

ABSTRACT

Moral evolution theories have emphasized kinship, reciprocity, group selection, and equilibrium selection. Yet, moral virtues are also sexually attractive. Darwin suggested that sexual attractiveness may explain many aspects of human morality. This paper updates his argument by integrating recent research on mate choice, person perception, individual differences, costly signaling, and virtue ethics. Many human virtues may have evolved in both sexes through mutual mate choice to advertise good genetic quality, parenting abilities, and/or partner traits. Such virtues may include kindness, fidelity, magnanimity, and heroism, as well as quasi-moral traits like conscientiousness, agreeableness, mental health, and intelligence. This theory leads to many testable predictions about the phenotypic features, genetic bases, and social-cognitive responses to human moral virtues.

\section{INTRODUCTION}

A MONG HUMANS, attractive bodies may elicit short-term desire, but attractive moral traits can inspire long-term love. Is this a coincidence, or are there some functional similarities between sexual ornaments and moral virtues? Many sexually attractive physical traits evolved to reveal phenotypic condition and genetic quality, including health, fer- tility, and longevity (Langlois et al. 2000; Fink and Penton-Voak 2002). This paper explores the possibility that some human moral traits evolved through sexual selection to serve an analogous display function. The most romantically attractive mental traits (i.e., kindness, bravery, honesty, integrity, and fidelity) often have a moral dimension.

Recent empirical research suggests that

The Quarterly Review of Biology, June 2007, Vol. 82, No. 2

Copyright (C) 2007 by The University of Chicago. All rights reserved.

0033-5770/2007/8202-0002\$15.00 
many moral traits are sexually attractive, and may serve as mental fitness indicators: they are judged as reliably revealing good mental health, brain efficiency, genetic quality, and capacity for sustaining cooperative sexual relationships as well as investing in children (e.g., Gurven et al. 2000; Hawkes and Bliege Bird 2002; Alvard and Gillespie 2004). Thus, the moral virtues that we consider sexually attractive are not culturally or evolutionarily arbitrary. Rather, they evolved to advertise individual fitness (including genetic quality as well as parenting and relationship-coordination abilities) in hard-to-fake ways that can be understood through a combination of sexual selection theory (Kokko et al. 2002; Andersson and Simmons 2006) and costly signaling theory (Gintis et al. 2001; McAndrew 2002). ("Fitness" here means adaptive design for reproductive success, or the statistical propensity to survive and reproduce successfully; it may not equal achieved reproductive success under evolutionarily novel conditions, especially given contraception.)

The hypothesis is that sexual selection shaped some of our distinctively human moral virtues as reliable fitness indicators. Precursors of many human virtues, such as empathy, fairness, and peacemaking, have been discovered in other great apes (Preston and de Waal 2002; Brosnan and de Waal 2003). My claim is not that sexual selection created our moral virtues from scratch in our species alone; rather, sexual selection amplified our standard social-primate virtues into uniquely elaborated human forms.

This mate choice model is intended to complement, not replace, other models of human moral evolution. Besides sexual selection, various forms of social selection probably shaped human morality, including:

- kin selection (Hamilton 1964);

- reciprocal altruism (Trivers 1971; Ridley 1996; Sugiyama et al. 2002);

- discriminative parental solicitude (Trivers 1974; Mock and Parker 1997);

- commitment mechanisms (Frank 1988; Nesse 2001);

- risk-sharing mechanisms (Boone 1998; Sugiyama and Sugiyama 2003);

- social norm and punishment mechanisms
(Henrich and Boyd 2001; Fehr and Fischbacher 2004);

- group selection (Sober and Wilson 1998); and

- equilibrium selection among alternative evolutionary strategies (Boyd and Richerson 1990; Alvard and Nolin 2002).

Each of these moral evolution models has led to valuable insights and progressive research traditions. Some are better at explaining moral virtues such as love of children, siblings, and parents, and righteous anger at cheaters and promise-breakers. This moralitythrough-mate-choice model also has distinctive strengths and weaknesses that can explain some moral virtues-especially those that show high sexual attractiveness, assortative mating, phenotypic and genetic variance, heritability, condition-dependent costs, conspicuous display in courtship settings, and young adult age peaks in display. Yet, for each of the traditional mechanisms above, sexual selection should anticipate, sharpen, and amplify the social selection pressures to produce a more extreme, costly, prosocial version of the moral virtue than social selection could achieve alone. The reason is that nonsexual forms of social selection can shape morality only insofar as they confer fairly concrete survival benefits (e.g., shared food, protection from predators) on the morally virtuous. Mate choice can shape morality much more powerfully and broadly because it demands only that moral behaviors carry some signaling value about a potential mate's good genes and/or parent/partner abilities. In general, sexual selection can "supercharge" other evolutionary processes by adding positive feedback dynamics that tend to trigger evolutionary innovation and speciation (Miller and Todd 1995; Crespi 2004). If a moral virtue becomes useful in kinship, reciprocity, or group prosperity, our ancestors probably did not ignore it when choosing mates.

Some moral virtues may be attractive as signals (e.g., heroism as a signal of competence), whereas others may seem attractive as traits in their own right (e.g., fairness as an intrinsically valuable trait in a long-term sexual relationship). This distinction requires caution, however, because there is almost always scope for misrepresenting one's traits 
during courtship. A potential mate may act agreeable and easygoing during courtship, then become irritable and cantankerous after a couple years. In this case, courtshipagreeableness was valued as a signal of likely future relationship-agreeableness, but it proved unreliable. Sexual commitment often brings moral disappointment. The costly signaling perspective is helpful in identifying such pitfalls-not only situations where one trait is unreliably correlated with another, but also situations where the present value of a trait is unreliably correlated with its future value. From this viewpoint, all moral virtues displayed during sexual courtship are potentially fallible signals of other traits or future traits, so their reliability and stability must be analyzed in a costly signaling framework.

To propose that human moral virtues evolved through mate choice is not to suggest that human morality is sexually motivated at the level of individual behavior. Evolutionary functions do not equal proximate motivations (Radcliffe Richards 2000; Pinker 2002). Even if the evolutionary payoffs for moral behavior were mainly reproductive, moral behavior can arise at the proximate level from genuinely moral personalities and motives (Frank 1988; de Waal 1997), not just copulatory motives. Indeed, sexual patience is a key virtue in courtship: if a potential male mate shows sexual self-restraint for a long time, this protects female mate choice, signaling that the male is not just looking for a short-term affair or extra-pair copulation.

This paper argues that there is substantial overlap between sexually attractive personality traits and human moral virtues, but does not pretend that all sexually attractive traits are virtues, or that all virtues are sexually attractive under all conditions. Some individuals may feel most aroused by potential mates who show Machiavellian cunning (Whiten and Byrne 1997), aggressive ferocity (Chagnon 1988), or rampant promiscuity (Oliver and Sedikides 1992). To argue that some moral virtues evolved through mate choice is not to argue that vice is never attractive.

\section{Moral Virtues and Virtue Ethics}

This paper tries to integrate relevant insights from individual differences research, behavior genetics, and moral philosophy. It goes beyond my book, The Mating Mind (Miller 2000a), by emphasizing relevant empirical and theoretical work since 2000. For example, it connects recent person perception research with person-level approaches to moral philosophy, especially virtue ethics (Flanagan 1991; Stohr and Wellman 2002) and naturalistic approaches to understanding moral intuitions (e.g., Nesse 2001; Dennett 2003).

I do not assume that the "virtues" historically identified by philosophers will equal the moral adaptations that can be identified in humans using standard adaptationist criteria of special design (e.g., Andrews et al. 2002). Nor do I assume that the idealistic reasons for advocating certain virtues in normative ethics will have anything to do with the selection pressures that may have actually shaped those virtues phylogenetically. So why mention virtue ethics at all? First, virtue ethics provides a useful counterbalance to the traditional consequentialist (utilitarian, payoff-based) ethics that have influenced previous evolutionary theories of altruism (e.g., kin selection and reciprocal altruism). Also, as I will argue in a later section, virtue ethics shifts the level of analysis usefully from isolated altruistic acts to stable personality traits. Third, many virtue ethicists write carefully and insightfully about our emotional and cognitive responses to other people's virtues and vices (e.g., Flanagan 1991), and their work can be construed as a useful first draft of the qualitative, descriptive moral psychology that may prove useful in understanding the "receiver psychology" of moral signaling. Finally, virtue ethics offers a new route whereby evolutionary theory can influence the contemporary humanities and social sciences. Thus, my allusions to virtue ethics are intended in the spirit of maximizing the interdisciplinary relevance of adaptationist research.

\section{Costly Signaling Theory, Fitness Indicators, AND Moral Virtues}

Costly signaling theory has its intellectual roots in many traditions and academic fields, some of which construed human moral virtues as costly signals. In Friedrich Nietzsche's 
(1887) On the Genealogy of Morals, pagan virtues were considered attractive signals of health and power. In Thorstein Veblen's (1899) The Theory of the Leisure Class: An Economic Study in the Evolution of Institutions, conspicuous consumption and conspicuous charity were seen as hard-to-fake signals of wealth and social status. In 1970s biology, Amotz Zahavi (1975) viewed many animal signals and prosocial behaviors as hard-tofake indicators of animal fitness (Zahavi and Zahavi 1997).

Since about 1990, costly signaling theory has revolutionized the study of both sexual selection and human altruism (Gintis et al. 2001; McAndrew 2002). Most animal communication is relentlessly narcissistic, advertising the signaler's own individual species, sex, age, health, fertility, social status, phenotypic condition, and/or genetic quality (Bradbury and Vehrencamp 1998). However, animals often have incentives to lie about their own qualities to attract more mates, solicit more parental investment, or deter more predators and rivals. Costly signaling theory offers a solution to this problem of lying: if a signal is so costly that only high health, high status, high condition animals can afford to produce it, the signal can remain evolutionarily reliable (Zahavi and Zahavi 1997).

Almost any fitness-related cost will work: matter, energy, time, or risk. For example, a peacock's tail is burdensome in all four senses: its growth and maintenance requires several hundred grams of mass, many calories, a long time to grow, and much risk; its costs undermine immunocompetence and parasite resistance (Møller and Petrie 2002; Loyau et al. 2005). Often, the most complex, elaborate, and puzzling signals observed in nature are the result of sexual selection through mate choice (Darwin 1871). These sexual ornaments almost always impose high costs on the bearer, guaranteeing their reliability as indicators of condition and fitness.

This paper argues that many human virtues evolved through sexual selection as costly signals. This hypothesis has been advanced by a few previous researchers (e.g., Darwin 1871; Hawkes 1991; Tessman 1995; Zahavi and Za- havi 1997; Roberts 1998), and its empirical testing has been one of the most active areas of evolutionary psychology and evolutionary anthropology in the last few years. Indeed, many prosocial behaviors that were assumed to arise through kinship or reciprocity are now thought to have emerged as costly signals of individual fitness favored by social and sexual selection.

For example, it was often assumed that risky big-game hunting evolved so the best hunters could better feed their own offspring (Stanford 1999). However, most hunted meat from big game is distributed too widely in hunter-gatherer clans for this paternal provisioning theory to work (Hawkes et al. 2001; Alvard and Nolin 2002). Recent research suggests that the most successful hunters, who provide the prosocial public good of hunted meat, also tend to attract more high quality female mates (Gurven et al. 2000; Sosis 2000; Hawkes and Bliege Bird 2002; Alvard and Gillespie 2004). Meat-provisioning may not be a conscious sexual strategy, or even the causal mediator of good hunters' increased reproductive success; good hunting and high attractiveness may both be caused by an underlying trait such as high genetic quality. Nevertheless, such research raises the possibility that altruistic meat-provisioning was favored, at least in part, by sexual selection.

Likewise, our mate preferences for other moral virtues may be explained by costly signaling theory. If a young woman places a single's ad stating, "SHF, 26, seeks kind, generous, romantic, honest man," we might translate this in evolutionary terms as "single Hispanic female, 26, seeks a healthy male of breeding age with a minimal number of personality disorders that would impair efficient coordination and parenting in a sustained sexual relationship, and a minimal number of deleterious mutations on the thousands of genes that influence the development of brain systems for costly, conspicuous, altruistic displays of moral virtue." Of course, this hypothetical ad itself is not good psychological evidence or a costly signal in its own right-it is cheap and easy to fake. Rather, the ad identifies some desired moral virtues that would be difficult to fake consistently during a lengthy courtship. 
GOOD GENES, GOOD PARENTS, AND GOOD PARTNERS

Sexually-selected costly signals typically advertise two classes of traits: good genes or good parenting abilities (Kokko et al. 2002). Different moral virtues might advertise one or the other, or both. They might also advertise the capacity to be a good partner in a long-term sexual relationship-someone reliable, trustworthy, adaptable, agreeable, and efficient at coordinating joint activities.

Good genes indicators advertise general "genetic quality," which probably reflects having a low "mutation load" (i.e., fewer than average errors in DNA replication) (Ridley 2001). By favoring mates with a below average number of harmful mutations, sexually reproducing organisms can increase the expected survival and reproductive prospects of their offspring, even if their mate contributes nothing as a parent after fertilization (Houle and Kondrashov 2002).

Moral virtues may function as good genes indicators by being difficult to display impressively if one has a high mutation load that impairs the precision of body and brain development. For example, displaying a sophisticated, empathetic social intelligence requires the development of a complex Theory of Mind, which might be easily disrupted by a variety of mutations associated with autism, schizophrenia, mental retardation, social anxiety, and language impairments (Baron-Cohen 2002; Shaner et al. 2004; Keller and Miller 2006). Thus, a conspicuously expert level of empathy may function as a sort of neurogenetic warranty. For moral virtues to function as good genes indicators, they must show at least moderate degrees of genetic variance, heritability, and positive genetic correlations with other fitness-related traits (Shaner et al. 2004; Prokosch et al. 2005; Miller and Penke 2006).

By contrast, good parent indicators advertise phenotypic traits that help care for offspring, such as feeding them, grooming them to remove parasites, protecting them from predators, resolving sibling rivalries, and teaching life skills through play and practice (Kokko 1998). A genuinely empathic personality may also function as a good parent warranty, guaranteeing the likely patience, kindness, protectiveness, playfulness, and conscientiousness that helps children thrive. For moral virtues to function as good parent indicators, they need not show genetic variance, heritability, or genetic correlations with other fitness-related traits; they need only show reliable phenotypic correlations with parenting-relevant abilities.

Finally, good partner indicators advertise phenotypic traits that promote efficient coordination and high mutual benefits in longterm sexual relationships. In game theory terms, such relationships (e.g., marriages) are iterated, mixed-motive games with very complex conflicts and confluences of interest, many possible equilibria, and incomplete information about the other player's possible tactics and preferences. Some of a potential mate's moral virtues could function as signals that maximize one's payoffs and minimize one's risks in such relationship games. For example, moral capacities for conscientiousness and patience may signal a partner's likelihood of playing mutually beneficial strategies given the repeated interaction nature of longterm relationships. Moral capacities for empathy and sympathy may signal that a partner attaches positive utility to one's own happiness in addition to their own, which makes it much more likely that a Pareto-optimal (mutually beneficial) equilibrium will be maintained in the relationship. A moral preference for romantic commitment over violent aggression may signal that a partner will seek to sustain a cooperative relationship through promises rather than threats. In each case, the moral trait as a good partner indicator may seem intuitively attractive for its own sake, since conscientious, empathetic, committed partners make life easier. As noted earlier, however, whenever there are incentives to act like a better partner during courtship than after reproduction, the problem of trait stability arises.

Mate preferences for human moral virtues, whether as good genes, good parent, or good partner indicators, may have originated in other social preferences concerning kin selection (Hamilton 1964), reciprocal altruism (Trivers 1971), social commitment (Nesse 2001), progeny choice (Mock and Parker 
1997), or other domains. For example, psychological adaptations for detecting, remembering, and avoiding cheaters in the domain of social reciprocity (Sugiyama et al. 2002) could have been extended ("exapted") to the domain of mate choice as a preference for the moral virtues of honesty and reliability. Indeed, mate preferences for moral virtues may have originated as nonfunctional byproducts of these other social preferences, and would have been more appropriately analyzed using "receiver bias" models (e.g., Ryan 1998) rather than costly signaling models of sexual selection. Given the central adaptive importance of mate choice, however, it seems likely that such nonfunctional preferences would have been rapidly eliminated (if they had net fitness costs), or modified and specialized for adaptive mate choice (if they had net fitness benefits) (Kokko et al. 2002).

\section{SEXUALLY SELECTED SIGNALS AND SEX} DIFFERENCES

From a costly signaling perspective, sexual selection is not restricted to explaining sex differences; it can also explain sexual similarities (nondimorphism) in extravagant traits when mutual mate choice is at work (Kokko and Johnstone 2002). Humans are unusual among mammals in showing intensive offspring care by both mothers and fathers (Geary 2000), which favors roughly equal levels of male and female mate choice for long-term socially monogamous relationships (Kenrick et al. 1990). This has resulted in low-dimorphism physical ornamentation in humans (e.g., long head hair, relatively hairless bodies, and everted lips) and low-dimorphism psychological ornamentation (e.g., cognitive abilities for language, art, music, humor, and ideology) (Miller 2000a). Thus, a sexual selection account of moral virtues does not imply that males evolve all the conspicuous virtues and females play the passive role of virtueassessment (cf. Darwin 1871). Given mutual choice, both human sexes should show conspicuous, sexually attractive moral virtues during mate attraction and retention.

Human males face higher variance in reproductive success, however, so they are predicted to allocate somewhat more energy, time, and risk to mating effort, including costly, dangerous, public displays of moral virtue. For example, this model naturally explains why males are overrepresented among prosocial heroes who risk their lives to save unrelated strangers (Farthing 2005). It may also explain why males remain overrepresented in high risk, underpaid, altruistic, romantically attractive professions such as the police, fire, and military services, whereas women remain overrepresented in low risk, underpaid, altruistic, romantically attractive professions such as nursing and school teaching. The biased sex ratios in these high risk versus low risk professions are undoubtedly influenced by social norms regarding gender, danger, and sex roles (Byrnes et al. 1999). Nonetheless, human gender norms seem unlikely to be the whole explanation, given the cross-species ubiquity of sex differences in risk-taking (Campbell 1999) and the evidence that human sex differences in risk-taking are largely mediated by sex differences in personality traits such as sensation-seeking, aggressiveness, and extraversion, rather than gender roles concerning risk (Zuckerman and Kuhlman 2000).

More generally, sexual selection is probably relevant whenever there are cross-culturally stable sex differences in the display or judgment of human moral virtues. By contrast, most traditional theories of human moral evolution through kinship, reciprocity, group selection, and equilibrium selection are sexblind. Therefore, they have trouble accounting for any observed sex differences in the means, variances, heritabilities, genetic correlations, and life-history profiles of specific quantifiable moral virtues and any associated social, political, or religious attitudes (e.g., Barriga et al. 2001; Skoe et al. 2002).

\section{EVALUATING MORAL PERSONS VERSUS MORAL ACTS}

Costly signaling theory portrays human moral actions in a new light, as reliable cues of personal moral traits. This may seem a peculiar idea to most moral philosophers, who have traditionally focused on judging the morality of isolated acts rather than the moral virtues of a person as a whole. Recently, as act 
ethics has been supplanted by virtue ethics (Stohr and Wellman 2002), attention has returned to the moral-person level of description-just the right level of description to consider in costly signaling models of moral evolution. It is the level that unifies the study of quantitative traits in evolutionary genetics, mate choice in evolutionary psychology, person perception in social psychology, personality traits in behavior genetics, parole decisions in criminal justice, and voter choice in democratic elections.

It seems unlikely that our prehistoric ancestors made moral judgments about isolated behavioral acts. Rather, as in other domains of person perception (Funder 2004), they probably interpreted the behavioral acts as cues of stable individual traits (virtues or vices). In small-scale hunter-gatherer bands, morality came in person-sized units, not actsized units. Ancestral hominids had to choose their lovers, friends, and allies as integrated moral packages-good or bad, hero or villain, lover or stalker, reciprocator or cheat.

Moreover, it would not make adaptive sense to judge isolated moral acts in tightlyknit prehistoric social groups. Individual actions must be assessed in the context of individual qualities, such as age, sex, status, physical and mental health, personality, intelligence, and genetic relatedness. We tolerate theft by our own toddlers more than theft by unrelated adults. We forgive unkind words spoken by the sick during high fevers. We do not expect a keenly empathic Theory of Mind in the severely brain-damaged or autistic. Also, individual actions must be assessed in the context of ongoing relationships, as different social interaction domains call for different moral judgment criteria, focused on different virtues. We may favor kindness and fidelity more in mate choice, honesty and conscientiousness more in reciprocity, and genetic similarity, residual reproductive value, and gratitude more in kin-directed altruism. This is why mothers can love their psychopathic sons. Only in social reciprocity with unrelated acquaintances do we see the tit-for-tat moral accounting that corresponds to traditional act ethics (see Sugiyama et al. 2002).

The moral person and moral act levels of description show some other key differences relevant to this mate choice model. First, "morality" means something different at the person level compared to the act level. A moral act may be one that obeys some rationally defensible, universal, deontic, or consequentialist principle. However, from the point of view of a standard prehistoric hunter-gatherer, a moral person is someone who embodies prosocial virtues that make him or her a good mate, friend, relative, or trading partner. In evolutionary terms, a moral person is simply one who pursues ultimate genetic self-interest through psychological adaptations that embody a genuine, proximate concern for others (de Waal 1997; Nesse 2001).

Second, the moral person level emphasizes that perceived moral virtue is an emergent property of interaction between the moral judgment maker and the morally judgedjust as beauty arises from the sexual ornaments of the displayer interacting with the perceptual adaptations of the beholder (Symons 1995). Beauty is neither subjective nor objective, but what one could call "objectively relational:" it is a real emergent property of a costly signaling system including both ornaments and preferences. Likewise, for moral virtues in this mate choice model, the morality emerges from the interaction of traits and preferences. By contrast, the moral act level of description tends to downplay the role of the observer in making moral judgments, pretending that there can be direct contact between a moral act to be judged and a universal normative principle, such as Kant's categorical imperative or Mill's utilitarian principle.

Finally, we generally accept that "ought implies can" when we judge moral acts (SinnottArmstrong 1984). We do not expect the poor to donate to charity, or quadriplegics to jump in front of trolleys to save children. They cannot do the moral thing, so we do not expect it. However, when judging the morality of whole persons in real relationships, we are rarely so forgiving. If a potential mate has Tourette's syndrome and cannot refrain from screaming "psycho prick!" repeatedly during a public first date, a second date is unlikely, no matter how much we understand about verbal disinhibition in neurological disorders. If a potential hunting partner suffered 
a severe head injury that renders him too clumsy to hunt effectively, we may pity him, but will still exclude him from the hunt. When the fitness stakes are high, we hold people morally accountable, even for faults that are not their own. Moral culpability is a slippery idea, since everyone must be a joint product of their genes, environment, and random developmental events (Pinker 2002; Dennett 2003). If our ancestors could not ostracize helplessly evil people, they could not have protected themselves from serial rapists, psychopaths, or hot-tempered murderers.

\section{Romantic Virtues and Moral Virtues}

This sexual selection model may appear bizarre at first to moral philosophers and moral psychologists. From Saint Augustine through Sigmund Freud, sexuality has been viewed as morality's nemesis. When Western thought was gripped by the traditional dichotomies of body versus spirit, lust versus virtue, and sinners versus saints, it was hard to imagine that moral virtues might arise through mate choice. Even within evolutionary theories of morality, moral capacities are usually seen as efficient tactics to increase individual or group survival prospects rather than as costly, conspicuous signals to increase individual reproductive prospects.

To overcome these intellectual biases, it may help to take a step back and consider the role of moral virtues in real human mate choice. Apart from physical appearance and social status, which traits most excite our romantic impulses? People often fall in love based on positive assessments of each other's generosity, kindness, honesty, courage, social sensitivity, political idealism, intellectual integrity, empathy to children, respectfulness to parents, or loyalty to friends. The most romantic personal traits are often those that have been considered praiseworthy moral virtues by the world's most influential philosophical and religious traditions from ancient Greece, Israel, Arabia, India, China, and Japan. These attractive virtues include not only the traditional prosocial virtues of European Christendom (e.g., faith, hope, charity, love, kindness, fairness, equality, humility, and conscience), but also Nietzsche's (1887) pagan virtues (e.g., leadership, bravery, strength, skill, health, fertility, beauty, tolerance, joy, humor, and grace).

COURTSHIP AS A MORAL OBSTACLE COURSE

Moral virtues are, among other things, personal traits that we are proud to display during courtship. Indeed, courtship in most cultures can be viewed as a moral obstacle course- $-\mathrm{a}$ ritualized test of diverse moral virtues, such as kindness in gift giving, conscientiousness in keeping promises, empathy in listening, and sexual self-control. For courtship to be reliable, valid, and discriminating as a moral test, it must lead to a perceivable range of moral failures (e.g., broken promises, revealed prejudices, irritabilities, infidelities, impatient sexual pressures) that reflect an underlying population distribution of moral traits.

In archetypal romance stories across cultures, both characters fall in love, enjoy bliss, grow lazy, commit some moral errors, have a moral crisis, recognize their moral failures, resolve to improve their moral character, magnanimously forgive each other, and live happily ever after. It is not romantic for characters to make and forgive purely perceptual failures (e.g., failures of depth perception or color constancy) or purely cognitive failures (e.g., base-rate neglect or hindsight bias). If neither individual in a sexual relationship cares about projecting moral virtues (as in relations between prostitutes and clients or masters and slaves), then the relationship is considered superficial and unloving.

Subjectively, romantic emotions seem to amplify the perceived variance in moral character across potential lovers. When we fall in love, new lovers seem morally exemplary; when they make moral errors, they seem morally treacherous; when they make amends, they seem morally redeemed; when they divorce us, they seem morally repulsive. Borderline personality disorder (the tendency to view intimate partners in unstable, dichotomized ways, as alternately extremely good or extremely evil) (Koenigsberg et al. 2002) is just an exaggerated form of the normal human tendency to alternately overvalue and undervalue our lovers' virtues. Of course, 
such emotions may not increase the objective accuracy of moral information (in the sense of more accurate perceptual discrimination of moral traits across individuals), but they may increase the salience of such information-its accessibility to other brain systems for attention, memory, decision making, language, and motor behavior.

Conversely, moral vices are character flaws that we would be embarrassed to reveal to potential mates. These sexually embarrassing vices include not just obviously antisocial behaviors (killing, raping, lying, cheating), but also victimless addictions (sloth, gluttony, greed, envy, pride, drinking, smoking, drug-taking, gambling, masturbating), failures of prosocial magnanimity (undertipping waiters, ignoring starving children, fleeing combat), and acts of symbolic meanness (kicking toys, burning books, spitting on tombs). Although this may sound like an odd assortment of crimes, sins, foibles, and insanities from most traditional viewpoints (evolutionary altruism theories, law, religion, psychiatry), from a virtue ethics viewpoint (and from the sexual signaling viewpoint of this article), these moral vices have an important common denominator: they lead potential mates to hold our moral character in lower esteem, making them less likely to breed with us. Also, the leading causes of divorce across cultures (infidelity, abuse, addiction, unemployment (Betzig 1989)) are almost all seen as serious moral failures. To moral philosophers, the sexual costs of moral vice may seem tangential to human moral evolution. Yet, to evolutionary biologists, a direct connection between moral vice and impaired reproductive success should be highly suggestive.

\section{Example: Courtship Generosity}

The moral virtues most readily explained by sexual selection are those most conspicuously manifest in sexual courtship and relationships, and consistently valued in mate choice across cultures. Courtship generosity is the most obvious example, with clear parallels to courtship feeding by animals, in which nuptial gifts are given by males to females as good-genes indicators and good- parent investments (Vahed 1998). Human courtship generosity would include altruism, kindness, and sympathy to the sexual partner, to his or her children from previous relationships (step-children), and to his or her family members (in-laws). Since this sort of courtship generosity is directed at nonrelatives and is not expected to be reciprocated, it is hard to explain through kin selection or reciprocal altruism. It qualifies as evolutionary altruism by traditional definitions.

Courtship generosity may even include much of the paternal effort that is usually assumed to arise through kin selection (where "kin" include "offspring"), since most divorced fathers reduce their paternal investment as soon as they are denied sexual access to mothers (Hofferth and Anderson 2003). Thus, what looks like simple paternal investment in one's offspring may turn out to be better described as ongoing courtship generosity by males to maintain sexual access to the mothers of those offspring. Under ancestral small-group conditions, it may have been perfectly clear which males cut off aid to their children after ending relationships with their mothers. Such males may have been considered immoral and selfish, and may have suffered reputational and reproductive costs as a result. Depending on the exact social context and social norms, however, those moral costs may have been lower than the net fitness costs of continued paternal investment without sexual access to the mother. As with all complex psychological adaptations, recognition of such situational contingencies is not handwaving; it can lead to precise, testable predictions about the social, cultural, and economic conditions under which males will continue paternal investment following relationship termination.

\section{Moral and Quasi-Moral Traits in Individual Differences Psychology}

Some of the best-studied individual differences dimensions in psychology have moral or quasi-moral status when they are assessed in social and sexual interaction. These include personality traits, mental health traits, and intelligence. These heritable dimensions of individual variation are morally valenced, 
and their morally praiseworthy extremes increase sexual attractiveness. These traits are interrelated not because they share some abstract set of necessary and sufficient conditions, but because, in the real world, they tend to be disrupted by the same kinds of pleiotropic genetic mutations, developmental errors, and neuropsychological abnormalities.

\section{PERSONALITY TRAITS}

Current research on personality traits is dominated by the "Big Five" model, which identifies five key personality traits that can be reliably measured, that validly predict diverse behaviors, that are stable across the lifespan, and that replicate across cultures (Costa and McCrae 1992; Matthews et al. 2003; Funder 2004). These traits can be remembered with the acronym OCEAN: openness to experience, conscientiousness, extraversion, agreeableness, and neuroticism. Of these, conscientiousness and agreeableness are most strongly sought in long-term mates (Botwin et al. 1997; Berry and Miller 2001; Donnellan et al. 2004; Ozer and BenetMartinez 2006), and best predict good partner traits (Noftle and Shaver 2006; Ozer and Benet-Martinez 2006) and good parent traits (Spinath and O'Connor 2003; Kochanska et al. 2004), so are most likely to have been shaped as moral virtues by sexual selection.

Conscientiousness implies fulfilling promises, respecting commitments, and resisting bad habits. It subsumes individual differences in industriousness, self-control, responsibility, and several other virtues (Roberts et al. 2005). It predicts emotional maturity (McCrae et al. 1999) and romantic loveability in relationships (Engel et al. 2002). It also predicts prosocial civic and organizational engagement (Organ and Ryan 1995), as well as honesty, integrity, dependability, trustworthiness, and reliability at work (Sackett and Wanek 1996). Further, conscientiousness positively predicts virtually every health-related behavior that increases longevity, including eating a healthy diet, exercising, and avoiding tobacco, excessive alcohol, addictive drugs, risky sexual behavior, dangerous driving, and suicide (Bogg and Roberts 2004). Conscien- tiousness is also closely related to the capacity for willpower, self-control, and delay of gratification, which are key virtues across many sociosexual domains (Metcalfe and Mischel 1999). Prefrontal brain damage, as in the famous case of Phineas Gage (Damasio et al. 1994), tends to reduce conscientiousness and disinhibit impulsive antisocial behavior, so it reduces both moral virtue and long-term sexual attractiveness.

Agreeableness implies warmth, kindness, sympathy, and nonaggressiveness; it predicts benevolence and respect for moral traditions (Roccas et al. 2002), the quality and peacefulness of social relationships (Asendorpf and Wilpers 1998), and success in jobs requiring teamwork and social interaction (Mount et al. 1998). Gentle, agreeable behavior fits the "tend-and-befriend" response to stress that is favored by female social primates (Taylor et al. 2000). Individuals who score low on agreeableness tend to have more personality disorders (Saulsman and Page 2004). They also tend to be aggressive, arrogant, conceited, domineering, narcissistic, and lacking in empathy-usually considered moral vices. Since agreeableness increases satisfaction and stability in sexual relationships (Watson et al. 2000), as in other social relationships (Graziano et al. 1996; Asendorpf and Wilpers 1998), it is probably valued especially as a good parent and good partner indicator.

The other three of the Big Five traits (openness, extraversion, and neuroticism) are more morally ambiguous, and tend to result in assortative mating through preferences for self-similarity. For example, high openness (interest in novel experiences, aesthetics, and culture) predicts the moral virtues of emotional sensitivity (Schutte et al. 1998), social tolerance (Dollinger et al. 1996), political liberalism (McCrae 1996; Butler 2000), and support for universal values-the sort that would be supported by Kant's categorical imperative (Roccas et al. 2002). On the other hand, low openness predicts the moral virtues of temperance, chastity, stoicism, community solidarity, pride in one's people and traditions, and clarity of gender role (manliness or femininity) (see Kendler et al. 1997; Lacey et al. 2004) — which academics tend to label vices ("right-wing authoritarianism," racism, sex- 
ism) (Jost et al. 2003; Van Hiel et al. 2004). The strong assortative mating for political and religious attitudes reflecting each point along the openness dimension (Botwin et al. 1997; Watson et al. 2004) suggests that sexual selection may have amplified variance in openness, but is unlikely to have pushed it consistently in either direction.

Are personality traits such as conscientiousness and agreeableness really relevant to the evolution of morality? Moral philosophers have lately rediscovered the old social psychology critiques of personality psychology, as in the "person versus situation" debate (Mischel 1968), and work on the "fundamental attribution error" (Sabini et al. 2001). Social psychology's concern was that apparently stable personality traits may not really exist, but may only be projections of a biased socialattribution system. Citing this literature, Doris (1998) and Harman (1999) argued that virtue ethics cannot succeed because social psychology shows there are no stable personality traits that could correspond to virtues. Unfortunately, virtue ethicists (e.g., Merritt 2000) have not usually responded to these critiques on empirical grounds, by citing the well-established reliability, validity, stability, and heritability of personality traits (Matthews et al. 2003; Funder 2004), which have been established across cultures and even across species (Gosling 2001; King et al. 2005).

\section{MENTAL HEALTH TRAITS}

All major mental illnesses tend to increase perceived selfishness and to decrease perceived moral virtue, sexual attractiveness, and social status (McGuire et al. 1994). This seems especially true for the most common and severe psychopathologies, such as depression, schizophrenia, and psychopathy (Wilson et al. 1996; Nesse 2000; Shaner et al. 2004). Many personality disorders, such as paranoid, narcissistic, and borderline personality disorders, also predict antisocial behavior (Coid 2003). Signs of mental illness typically lead to social and sexual rejection by others, that is, to stigmatization through negative social attributions (Crisp et al. 2000). Serious mental illness almost always reduces reproductive success by reducing sexual attractiveness (e.g., Haukka et al. 2003). Indeed, many mental disorders can be viewed as catastrophic failures of "mating intelligence" —of the cognitive and motivational systems that allow normal individuals to display moral virtues, verbal creativity, and social savvy in courtship (Shaner et al. 2004).

Severe mental disorders disrupt moral virtues, but they disrupt almost everything else too (e.g., education, employment, relationships, hygiene). Do less severe, more common mental disorders, such as personality disorders, have especially harmful effects on sexually-preferred moral virtues? Many of them seem to, and have highly sex-skewed prevalence rates that suggest some involvement of sexual selection in their evolutionary etiology. Asperger syndrome (a milder, common version of autism) is a highly male-biased condition characterized by serious deficits in social empathy and communication that result in pervasive, consistent problems in attracting, retaining, and understanding sexual partners (Baron-Cohen 2002). Narcissistic personality disorder (extreme arrogance, grandiosity, and self-promotion) reflects obsessive overinvestment in conspicuous, public fitness displays to attract multiple short-term mates (Buss and Shackelford 1997; Robins and Beer 2001). Antisocial personality disorder and psychopathy (pervasive, highly male-biased patterns of callous, exploitative, impulsive, violent, and promiscuous behavior) can be construed as overreliance on deceptive, coercive, and shortterm mating tactics (Krueger et al. 2002; Dunsieth et al. 2004). Borderline personality disorder (a highly female-biased pattern of promiscuity, relationship instability, drug and alcohol abuse, risky driving, and impulsive behavior) is associated with many vices (Skodol et al. 2002a). All of these personality disorders seriously reduce long-term mating success, relationship satisfaction, and marital stability (Skodol et al. 2002b), and they have fairly high prevalence rates in the general population (Grant et al. 2004). Thus, the study of mental disorders and their effects on intimate relationships is highly relevant to understanding moral virtues and vices, as well as their possible origins through mate choice. 


\section{INTELLIGENCE}

Intelligence (in the sense of general cognitive ability, the $g$ factor, or IQ) is a morally valenced concept, which is why it has been so controversial throughout a century of psychometrics (since Spearman 1904). It is wellestablished that intelligence predicts objective performance and learning ability across all important life domains that show reliable individual differences (Jensen 1998; Deary 2000). Based on thousands of psychometric studies, almost all reputable intelligence researchers agree that the best single measure of intelligence is the $g$ factor (a dimension of general cognitive ability), which can be statistically extracted from any reasonably diverse battery of reliable cognitive tests given to any reasonably large sample (Carroll 1993; Neisser et al. 1996).

Less appreciated is that higher intelligence predicts many behaviors that we consider morally virtuous, such as being emotionally sensitive to the needs of others (Schulte et al. 2004), working conscientiously (Kuncel et al. 2004), staying healthy through exercise and diet (Gottfredson 2004), and staying happily married (Gottfredson 1997). Intelligence also predicts many forms of social, economic, and aesthetic success that are sexually attractive and morally valenced, including creativity (Miller 1999, 2000c; Kanazawa 2000), artistic virtuosity (Miller 2001), and achieving social status and wealth through individual merit (Ellis 2001). These moral correlates of intelligence may be one reason why intelligence is so attractive when both men and women consider potential long-term partners (Buss 1989; Kenrick et al. 1990; Li et al. 2002). Conversely, lower intelligence predicts many behaviors considered morally wrong, such as murder, rape, assault, alcoholism, drug addiction, absenteeism, child abuse and neglect, passing along sexually transmissible infections, and causing fatal traffic accidents (Gordon 1997; Lubinski and Humphreys 1997).

Many lines of research, from longitudinal studies to multivariate genetic studies, suggest that intelligence is not just correlated with these diverse traits and behaviors, but that in each case, intelligence is either causally primary, or intelligence and the other trait are driven by an underlying dimension of genetic quality (e.g., Jensen 1998; Plomin and Spinath 2002; Zammitt et al. 2004; Prokosch et al. 2005; Kovas and Plomin 2006).

One might object that intelligence is not really a moral virtue; it just happens to predict a wide range of specific moral behaviors. Yet, what is a moral virtue if not an individualdifferences dimension that predicts a wide range of specific moral behaviors? Moral virtues are socially attributed traits that carry predictive information about morally relevant behaviors. If kindness is a moral virtue because it predicts specific prosocial behaviors, and is valued as such, then intelligence must also be a moral virtue, along with being an academic, economic, and epistemological virtue. Another reason for accepting the quasi-moral status of intelligence is the recent convergence between virtue ethics and "virtue epistemology," the study of cognitive and intellectual virtues (Axtell 2000; Brady and Pritchard 2003; DePaul and Zagzebski 2003). Traditional epistemology tried to evaluate the truth of particular conceptual systems through consistency and coherence criteria. By contrast, for the virtue epistemologist, true beliefs arise from acts of intellectual virtue, those typical of intelligent, rational, cognitively complex agents (Zagzebski 1996) who show impartiality, epistemic responsibility, and intellectual courage (Code 1987; Kvanvig 1992; Montmarquet 1993). For example, Aristotle named intuition, wisdom, prudence, and science as intellectual virtues. In virtue epistemology, as in virtue ethics, the favored level of description is the whole individual as a cognitive/moral agent, not the isolated belief or moral act. This naturally leads to an emphasis on individual differences in epistemological virtue, differences that intelligence researchers have already succeeded in measuring with unparalleled reliability and validity for over a century (Jensen 1998). Thus, intelligence is a sexually attractive, quasimoral trait at the intersection of virtue epistemology and virtue ethics.

\section{Are These Traits Really Judged as Moral Virtues?}

In what sense do these personality, mental health, and cognitive traits have a quasi-moral 
status? There are at least four reasons to think they do-three from social psychology and one from popular culture. First, most people show a "just world belief" (Lerner 1980) that creativity, beauty, status, and wealth are merited by those who enjoy them, as both causes and consequences of moral virtue. People judge these traits as morally valenced and morally correlated. Second, research using the Implicit Association Test shows that many dimensions judged in person perception are highly evaluative and load on a common good/bad dimension that confounds moral goodness, likeability, pleasantness, status, racial similarity, and physical attractiveness (Greenwald et al. 2002). Third, there is a powerful "halo effect" around such traits, so they are judged as boosting the likely moral virtues of judged individuals (Eagly et al. 1991). For example, defendants in criminal cases who are physically attractive and high in social status are more likely to be acquitted or given lighter sentences by juries of their (often lower status) peers (McKelvie and Coley 1993). Conversely, information that a person is morally virtuous (e.g., honest) boosts ratings of their health and physical attractiveness (Paunonen 2006). Some halo effects may reflect accurate inferences about genuinely correlated traits (true halo), rather than perceiver bias (halo error) (Solomonson and Lance 1997; Jussim 2005). In each case, people conflate moral virtues with personality traits, mental health, intelligence, and physical attractiveness.

Finally, the popular culture reason: people often attribute these quasi-moral traits in exaggerated form to mythical beings who have strong moral valences, such as gods, patriarchs, political leaders, movie characters, and comic book superheroes. In religion, believers typically credit benevolent deities with supernatural levels of the quasi-moral personality traits (intelligence, conscientiousness, agreeableness, and emotional stability), as well as the standard sexually selected fitness indicators (size, strength, status, beauty, longevity) (Boyer 2001; Roes and Raymond 2003). In monotheistic religions, these traits are bundled together; in polytheistic religions, different supernormal traits are attributed to different deities. Contemporary fantasy films and comic books show the standard polytheistic pattern, with different supernormal quasi-moral traits attributed to different superheroes.

Ever since Socrates, philosophy has tried to develop precise distinctions between theoretical constructs that are often empirically correlated. Most philosophers think in terms of necessary and sufficient conditions, not in terms of factor analysis. Thus, moral philosophers may balk at such flagrantly irrational conflations of moral goodness, social reputation, economic power, and sexual attractiveness. Indeed, they may be tempted to quote a cautionary verse from Ogden Nash: "It's always tempting to impute / Unlikely virtues to the cute." But moral philosophers did not drive the genetic evolution of human virtues; ordinary people did. If we are seeking a descriptive explanation for human morality, we should attend to the person-perception judgments that may have causally driven moral evolution in our species. Ultimately, it is an empirical question whether ordinary people judge these traits to have a moral or quasimoral status when making social and sexual judgments about others.

\section{Are the Moral Virtues Really Sexually Attractive?}

Research shows that many particular moral virtues are sexually attractive and relationship-stabilizing; these include:

- kindness: emotional responsiveness to the needs of others (e.g., Jensen-Campbell et al. 1995; Li et al. 2002);

- empathy: lovingness, affection, fondness, commitment, forgivingness, trust, and perspective-taking (e.g., Kilpatrick et al. 2002; Fincham et al. 2004);

- niceness: agreeableness and nonviolence (e.g., Botwin et al. 1997; Gottman et al. 1998; Urbaniak and Kilman 2003);

- honesty (e.g., Boon and McLeod 2001; Haselton et al. 2005); and

- heroism (e.g., Johnson 1996; Kelly and Dunbar 2001; Farthing 2005).

Most of these moral virtue preferences are stronger when seeking a serious long-term partner than a short-term lover (Urbaniak 
and Kilman 2003). Others, such as the preference for risky, prosocial heroism, may be stronger when females are seeking a shortterm male partner (Farthing 2005).

The problem is that these studies have not been able to distinguish whether the moral virtues are preferred because they signal good genes, good parents, and/or good partners. As with most mate choice research, the first step is to demonstrate a preference that could drive selection for a signaling trait; the second step is to clarify why the preference exists, which often demands more nuanced, experimental research methods (e.g., Møller and Alatalo 1999). For example, if a certain moral virtue signals mainly genetic quality rather than parent or partner quality, it should be most preferred by women just before ovulation, within each monthly cycle, when it could be passed along to offspring (Gangestad et al. 2004; Haselton and Miller 2006). Likewise, good genes moral virtues should be more preferred in short-term sexual liaisons and extra-pair copulations than in long-term relationships. Conversely, good parent and good partner virtues should be more preferred by women at less fertile cycle phases, and in longer-term relationships. Much more research is needed along these lines.

\section{What about Cross-Cultural Differences in Moral Norms and Mate Preferences for Virtues?}

The cross-cultural studies of mate preferences cited above raise the question: if some moral virtues are species-typical, sexually selected indicators, why do we see large crosscultural differences in some moral norms and behaviors? Here again, the virtue ethics framework helps clarify different levels of analysis. I suspect that individuals from every culture tend to value intelligence, mental health, and emotional stability as moral virtues in potential mates, but that radically different behaviors can be used to demonstrate these traits in different social, cultural, economic, and ecological contexts.

The two largest cross-cultural studies of mate preferences have been coordinated by David Buss (1989) and David Schmitt (2004a,b). Buss (1989) and his collaborators asked 10,047 people from 37 cultures to rate and rank the desirability of several traits in a sexual partner. Among the top ten traits most desired by both men and women across almost all cultures were: kindness, intelligence, exciting personality, adaptability, creativity, chastity, and beauty. Each of these has at least quasi-moral status in many cultures. Schmitt (2004a,b) and collaborators gathered data on 17,804 people from 62 cultures and found similarly close links between morality and mate choice. Across most cultures, sexual promiscuity, infidelity, and "mate poaching" were predicted by low agreeableness and low conscientiousness (Schmitt 2004a,b). Also, many studies show that singles' ads across cultures often advertise and seek moral traits, especially kindness, generosity, honesty, fidelity, and capacity for commitment (e.g., Oda 2001; Burmann et al. 2002; Koziel and Pawlowski 2003). Ideally, further research would examine cross-cultural preferences for moral virtues using more subtle, indirect, ecologically valid measures, such as revealed preferences in "fast dating" parties for real singles, rather than stated preferences on questionnaires and in singles' ads, which may be biased by strategic self-presentation and adaptive self-deception.

\section{SEXUAL SELECTION AND EQUILIBRIUM SELECTION}

An especially interesting, powerful, and neglected interaction may occur between sexual selection and group-level equilibrium selection (Boyd and Richerson 1990; Miller 2000a). Many evolutionary games have multiple equilibria (states where each player is maximizing their individual payoffs given the strategies already played by others). Some equilibria are better for everybody, bringing net positive payoffs to everyone ("Paretodominant"); some equilibria are worse for everybody ("Pareto-inferior"), but cannot be escaped easily because individuals who deviate from the equilibrium do even worse. Normally, natural selection alone is not very good at escaping from such Pareto-inferior equilibria to reach Pareto-dominant equilib- 
ria (Boyd and Richerson 1990). Sexual selection may help, by conferring reproductive benefits on individuals who deviate from selfish, antisocial equilibria (Miller 2000a). This sexual payoff for virtue is functionally similar to the social-reputation payoffs for virtue modeled by other researchers (e.g., Nowak and Sigmund 1998; Milinski et al. 2002; Barclay 2004).

However, standard social-reputation models create a second-order "free rider" problem (Gintis 2000): who will altruistically take the trouble to punish the wicked and reward the virtuous? As research from behavioral game theory (e.g., the Ultimatum Game) shows, most humans are emotionally compelled to impose this sort of "altruistic punishment" on others who act selfishly (Fehr and Gächter 2002); the question is why? Most explanations for altruistic punishment appeal to the dynamics of cultural evolution or social norms (e.g., Boyd et al. 2003), without identifying any plausible individual fitness payoffs for punishing the wicked. By contrast, this mate choice model identifies selfish matechoice incentives (e.g., good gene and good parent payoffs) for "rewarding" the virtuously punitive with sexual relationships. That is, the effective imposition of punishment on antisocial others (at substantial risks and costs to oneself) should be seen as virtuous, socially status-enhancing, and hence sexually attractive-and recent research suggests that it is (e.g., Henrich et al. 2001; Boyd et al. 2003; Nakamura and Iwasa 2005; Rucas et al. 2006; Seinen and Schram 2006). Thus, individual sociosexual payoffs for virtuous behavior can help solve the collective-action problems that pervade human social life. (Of course, prosocial punishers are likely to gain other costly signaling benefits, being viewed as more dominant, capable, and confident, and thus attracting more friends, allies, and support from kin.)

Most contemporary theories of moral evolution accept the importance of multilevel selection across genetic, individual, and group levels, either explicitly or implicitly (Sober and Wilson 1998). Generally, group-level selection for prosocial behavior is what breaks the symmetry between alternative equilibria in evolutionary games to allow the evolution of genuine empathy and altruism (Lahti and Weinstein 2005). This model of sexual selection interacting with group-level equilibrium selection is a potent way for prosocial virtues to establish a genetic beachhead in an otherwise selfish population, long before grouplevel equilibrium selection can favor morally unified groups.

\section{SEXUAL CHOOSINESS AS A MORAL VIRTUE}

In traditional sexual selection theory, there is a crisp distinction between mate preference and preferred trait (Darwin 1871; Kokko et al. 2002). However, if mate choice started to favor human sexual fidelity, chastity, and choosiness as moral virtues, the stage would be set for a new positive feedback process. Just as poor taste in friends and associates can reflect moral inadequacy, poor taste in previous mates can as well. Thus, in our highly social species, given capacities for observing, remembering, and gossiping about other people's sexual relationships, a conspicuously excellent capacity for mate choice could come under sexual selection as a preferred trait, perhaps even becoming a costly moral signal in its own right. The resulting evolutionary dynamics of such metaselection (sexual selection for sexual choosiness) have not, to my knowledge, been explored.

\section{Predictions of the Sexual Selection Model for Moral Virtues}

Given the theoretical plausibility of so many moral evolution models, how can they be tested empirically? This sexual selection model makes many discriminating predictions. These often take an unusual form, since costly signaling adaptations have very different phenotypic and genetic features compared to other types of adaptations. In particular, many of these predictions concern individual differences in virtues, whereas evolutionary psychology and moral philosophy have tended to focus on species-typical moral judgments and behaviors.

To test most of these predictions, one would need to develop measurement scales that can identify stable individual differences in particular kinds of moral virtues, and that fulfill standard psychometric criteria for reliability and 
validity. To discriminate between rival theories concerning the evolutionary origins and adaptive functions of specific human virtues, we need to assess the adaptive design features of each putative virtue in reliably quantitative ways. This will require much more psychometrically sophisticated approaches to virtue ethics, not just asking people to give answers to a few multiple-choice "trolley problems" from moral philosophy.

Generally, sexually selected virtues (as quantified in this way) should show most of the following 12 features. No one feature alone is strong evidence for the mate choice model, but these features are highly discriminating when used in combination, as they would not be expected from most other models of moral evolution through other selection pressures (e.g., kin selection, reciprocity, group selection), especially those that implicitly depend on stabilizing rather than directional selection. This list is intended mainly to help discriminate between different macromodels of moral evolution (e.g., sexual selection versus kin selection, reciprocity, and group selection), although certain criteria are also helpful in discriminating different micromodels within the sexual selection framework (e.g., virtues evolved as good genes indicators, good parent indicators, or good partner indicators).

\section{GENETIC FEATURES OF MORAL VIRTUES}

Positive heritability: If virtues are good genes indicators, they should prove genetically heritable in twin and adoption studies, with substantial additive genetic variance maintained by polygenic mutation-selection balance (Rowe and Houle 1996; Tomkins et al. 2004; Keller and Miller 2006). Many studies report substantial heritability for various forms of antisocial behavior and its personality correlates, such as psychopathy, sensationseeking, and disagreeableness (see Krueger et al. 2001; Rhee and Waldman 2002). Moderate heritability for altruism, empathy, nurturance, and/or responsibility has been found in a few twin studies (e.g., Zahn-Waxler et al. 1992; Davis et al. 1994; Rushton 2004). If virtues are costly and evolved under sexual selection, the genes underlying virtues should also show a distinctive life history of heritability and become more expressed only after sexual maturity, perhaps in response to sex hormones. This should lead to higher virtue heritability in adults than in children, as has been found with intelligence (Plomin et al. 2001). On the other hand, if virtues are mainly good parent and good partner indicators, they may show low heritability, though they should still show a distinctive life history that reflects the shifting costs and benefits of producing good parent/partner indicators, depending on whether one is sexually immature, mature but unmated, or mated securely.

Genetic inbreeding and paternal age effects: If virtues are good genes indicators, heritable variation in virtues should reflect variation in overall mutation load: the offspring of sibling or cousin marriages should show reduced virtue levels as a result of increased expression of harmful homozygous mutations (inbreeding depression). Also, since mutation load in sperm increases dramatically as men age (Crow 2000), all else being equal, younger fathers should sire more virtuous children. Such paternal age effects have been shown for various virtue-reducing mental illnesses, such as schizophrenia (Malaspina et al. 2002; Byrne et al. 2003) and autism (Reichenberg et al. 2006). Future research could use similar methods to investigate other virtues more directly.

Elusive molecular-genetic basis: Specific virtue-reducing alleles should be maintained mostly by mutation-selection balance. Thus, virtue-reducing alleles should be mostly of fairly recent evolutionary origin-recent, harmful mutations that have not yet been eliminated by sexual selection in particular breeding populations. Thus, despite the heritability of specific virtues, as found in twin and adoption studies, it should be extremely difficult to find specific "virtue genes" that replicate across human groups using standard linkage and association studies (Keller and Miller 2006). Rather than finding virtue genes, molecular geneticists should find mostly "vice genes," lineage-specific, evolutionarily transient, rare, recent mutations that decrease virtue, rather than common haplotypes that increase virtue. 
PHENOTYPIC FEATURES OF MORAL VIRTUES

Conspicuous courtship display: During courtship, individuals should conspicuously (if unconsciously) display virtues to the opposite sex. This could be measured across different time scales, comparing courtship to noncourtship situations across different ovulatory cycle stages, relationship stages, and social contexts. For example, priming people to think about potential romantic situations may increase their displays of conspicuous benevolence and heroism, as it does for displays of conspicuous creativity (Griskevicius et al. 2006) and conspicuous consumption (Wilson and Daly 2004). Good genes virtues should be selectively displayed more in short-term, opportunistic, or extra-pair mating (e.g., Johnson 1996; Kelly and Dunbar 2001; Gangestad et al. 2004; Farthing 2005); good parent/partner virtues should be displayed more in longterm mating (e.g., Goldberg 1995; Brase 2006).

Condition-dependent costs and positive correlations with other fitness indicators: Virtues should incur a significant cost to produce, in energy, time, risk, or nutritional resources (technically, they should incur a significant relative marginal cost) (Getty 2006). Without the condition-dependence requirement, this feature sounds tautological, insofar as altruistic virtues always imply evolutionary costs. However, with the condition-dependence requirement, we can make more specific falsifiable predictions. For example, individuals with higher genetic fitness or better phenotypic condition should be better able to bear the costs of conspicuous moral virtues as good genes indicators, so should more often display those virtues. Thus, good genes virtues should correlate positively with other wellestablished fitness indicators, such as physical and mental health, longevity, fertility, body size and symmetry, as well as intelligence (e.g., Gangestad and Simpson 2000; Gottfredson 2004; Prokosch et al. 2005). In particular, genuine phenotypic correlations should exist between good genes virtues, physical attractiveness, social status, and charisma, not just stereotyped "halo effects" in which more physically attractive people are seen as virtuous (cf. Eagly et al. 1991). By contrast, moral virtues as good parent/partner indicators may derive their temporal reliability (from early courtship to long-term relationship) not so much from condition-dependence as from the endogenous stability and increasing heritability of personality traits across the lifespan (McCrae et al. 2000; Roberts and DelVecchio 2000), the social-reputational costs of moral back-sliding (Brandt and Sigmund 2005), and the ever-looming threat of divorce for moral degeneracy (see Betzig 1989; Bradbury et al. 2000).

Comorbidity among vices, developmental instabilities, and brain abnormalities: If different virtue deficits reflect harmful pleiotropic mutations with partly overlapping effects, then vices should show positive genetic correlations (genetic comorbidity) with each other, especially as they become more serious and extreme. Also, if vices reflect harmful mutations that impair normal neurodevelopment, then they should be associated with various standard brain abnormalities widely observed for other fitness-reducing behavioral traits such as mental illness and mental retardation: smaller cortical volume, larger ventricles, abnormal cortical lateralization, and atypical localization of processing as observed in fMRI studies (Yeo et al. 1999).

Higher trait variance in males: In species that evolved with some degree of polygyny and some frequency of extra-pair copulation, the higher male variance and skew in reproductive success should favor a risk-seeking pattern of trait expression, such that male virtue levels show higher variance than female trait values (see Archer and Mehdikhani 2003). That is, there should be more conspicuously super virtuous males (e.g., Gandhi and Martin Luther King, Jr), but also more virtuedeficient males (e.g., Vlad the Impaler and Joseph Stalin). (The proclivity of conspicuously super virtuous males to have covert sexual affairs with many females is evidence for this mate choice model, not evidence that they were unvirtuous.)

Young adult peak in trait expression: For sexually selected behavioral traits, conspicuous virtue displays should peak in young adulthood, at the apex of mating effort. They should be low before puberty, increase rapidly thereafter, and then decline gradually as 
individuals shift their time and energy from courtship to parenting.

Alternative mating strategies: Individuals lacking the sexually attractive virtues should more often pursue alternative mating strategies that try to circumvent mate choice by the opposite sex and mate-guarding by same-sex rivals, just as animals with lower quality ornaments tend to do (Norman et al. 1999; Matsubara 2003). This may include increased use of short-term opportunistic mating, deceptive affairs, sexual harassment, sexual stalking, and/or sexual coercion (Thornhill and Palmer 2000; Baumeister et al. 2002; Dreznick 2003). If so, we might predict vicious cycle effects in which initially virtue-deficient individuals fail in the mating market and adopt increasingly desperate and exploitative alternative mating strategies, which further undermine their virtues. This is not a surprising prediction for behavioral ecologists, but it offers a view of sexual aggression quite different from the dominant feminist model in the social sciences (rape as a crime of patriarchal aggression, not sex, see Thornhill and Palmer 2000), and it may lead to more effective antirape interventions.

\section{MATE CHOICE FOR MORAL VIRTUES:}

Mate preferences: All else being equal, virtues should be favored in mate choice. They should be highly valued aspects of potential mates that individuals are motivated not just to judge passively by observation, but to probe actively by arranging various sociosexual situations that test the specific virtues of potential mates. (Such virtue tests are a central plot device in sitcoms and romantic comedies.) For example, a potential mate's honesty and fidelity may be tested by arranging for a same-sex friend to flirt with him or her and report the outcome. Further, virtues as good genes indicators should be favored more often in short-term relationships and extra-pair copulations, and by women at peak fertility near ovulation (see Gangestad et al. 2004; Haselton and Miller 2006). Virtues as good parent/partner indicators should be favored more often by individuals seeking longterm relationships, by those who already have children from previous relationships, and by women at lower fertility phases of the ovulatory cycle.

Positive assortative mating: In species with social monogamy such as ours, individuals should assortatively mate with respect to virtues because the competitive mating market should ensure that high virtue individuals prefer each other, leaving lower virtue individuals no choice but to settle for each other (Todd and Miller 1999).

Sexual derogation and gossip about trait values: If virtues are valued in courtship, same-sex rivals should selectively derogate each other with respect to virtue deficits such as lying and cheating (Schmitt and Buss 1996). Also, in social species such as ours, with collective mate-choice that takes into account the views of family and friends, gossip about potential mates should focus considerable attention on virtues as fitness indicators. Virtue should be praised and vices condemned, especially when people discuss potential mates for their kin and friends. This may sound tautological (what are virtues but socially praised traits?), but the mate choice model can lead to more specific predictions about sex differences and relationship context effects on the sexual derogation of virtues. For example, men seeking a short-term copulation value female promiscuity as a virtue (probably under a morally palatable euphemism such as fun, liberal, or adventurous), whereas men seeking a long-term relationship value female chastity as a virtue (Oliver and Sedikides 1992; Schmitt et al. 2001). Thus, a clever female will derogate or gossip about a shortterm sexual rival as a "frigid conservative," or a long-term marriage rival as an "insatiable nympho." Thus, the sexual attractiveness and moral valence of specific rival traits should reverse under predictable conditions.

\section{Example: Sexual Fidelity as a Moral Virtue}

Suppose a researcher hypothesizes that sexual fidelity evolved by sexual selection through mutual mate choice rather than through kin selection, reciprocal altruism, or group selection. Fidelity might minimize the spread of sexually transmissible pathogens, the risk of cuckoldry (a male investing in off- 
spring that were sired by another male), and the costs of polygyny (a female losing investment in her own children if a male sires children by another female). How could this hypothesis be tested? It might be easiest to go in reverse order of the 12 criteria listed above: start with mate choice for the virtue, then phenotypic features of the virtue, then genetic bases of the virtue.

A first step would be to investigate mate choice for fidelity. Do surveys, interviews, and experiments show that people prefer sexually faithful mates, all else being equal? Yes, although males are attracted to promiscuous females as potential short-term mates (Oliver and Sedikides 1992; Schmitt et al. 2001), neither sex respects high levels of promiscuity in potential long-term mates (Marks and Fraley 2005). Also, jealousy research shows that men and women across cultures react very negatively to sexual infidelity, yet are highly motivated to discover it (Buss 2000). Do people verbally derogate their sexual rivals for being unfaithful? Yes, moral derogation of sexual rivals (using morally charged terms such as skank, slut, or sleazeball) is a common mating tactic (Schmitt and Buss 1996; Bleske and Shackelford 2001). Do courting people often display their likely future fidelity to potential mates? Yes, lovers typically make impassioned, adaptively self-deceptive declarations of infinite, eternal, exclusive love.

If the moral trait shows most of these adaptive mating-related features, then the researcher might progress to phenotypic studies of sexual fidelity as an individual-differences dimension. Are there stable individual differences in the likelihood of fidelity versus infidelity, or is infidelity driven entirely by chance and opportunity? Research on the opposite of fidelity, the personality construct of "sociosexuality" (interest in promiscuous, short-term, or extra-pair mating), confirms there are stable individual differences in this trait dimension (Gangestad and Simpson 2000). Is fidelity positively correlated with other desirable moral virtues and fitness-related traits, such as kindness, conscientiousness, agreeableness, mental health, longevity, and intelligence? This question becomes complicated since individuals of higher mate value will be sought more often for short-term, extra-pair copulations, and thus will be tempted by more opportunities for infidelity (Gangestad and Simpson 2000). Mate value and infidelity opportunities would have to be carefully, statistically controlled in studies of fidelity's correlations with other moral virtues.

The genetic studies of infidelity would be the most difficult to perform, but often the most informative. Would twin and adoption studies show that the propensity to infidelity versus relationship stability is heritable? (Actually, they do already: Cherkas et al. 2004; Lyons et al. 2004). After controlling for overall mate value, would higher genetic inbreeding and paternal age reduce fidelity, suggesting a role for partially recessive harmful mutations in driving infidelity? Would one find positive genetic correlations between the tendency to fidelity and the mate preference for fidelity, as might be expected if there has been sexual selection for the trait?

Clearly, the sexual selection hypothesis for moral virtues is eminently testable. However, it requires new ways of thinking about costly signaling and sexually selected adaptations that are now commonly understood by evolutionary biologists, but that have been slow to permeate evolutionary psychology. In particular, evolutionary psychology still emphasizes criteria such as low cost, high efficiency, high modularity, low phenotypic variance, low heritability, and reliable development to identify psychological adaptations (e.g., Tooby and Cosmides 1990a,b; Andrews et al. 2002). These criteria are often appropriate for survival adaptations, but not for sexually attractive signals (Miller 2000b,c; McAndrew 2002). For naturalistic moral philosophy to benefit most from recent evolutionary insights, it must not only increase its appreciation of sexual selection's power, but also expand its understanding of how to analyze costly signaling adaptations by using, refining, and expanding the 12 expected features of moral virtues listed above.

\section{IMPLICATIONS FOR NORMATIVE ETHICS}

Normative ethics is supposed to help us distinguish right from wrong and good from evil. It tries to achieve a "reflective equilibrium" between (1) possible universal moral 
principles, (2) derived moral implications that would apply in particular situations, and (3) human moral intuitions that react to those principles, implications, and situations (Daniels 1996). The hope is that normative ethicists can articulate a set of universal, coherent, consistent moral principles that yield intuitively acceptable moral implications across all possible situations, thereby embodying a rational distillation of human moral sensibility. Almost all moral philosophers accept that this is the legitimate goal of normative ethics, though debates still rage between consequentialists and deontologists, act ethicists and virtue ethicists. However, if moral virtues arose through sexual selection, this reflectiveequilibrium approach to normative ethics will probably continue to fail, as it has for 2,500 years, for at least three reasons.

First, suppose human moral intuitions evolved as part of our person-perception system for inferring stable, morally valenced, mating-relevant personality traits from observable behaviors. If so, moral philosophers are trying to do ethical alchemy: trying to refine unconscious, domain-specific, personperception adaptations (the base metal) into verbally articulated, domain-general, universal moral principles (the gold). This is likely to be an uphill battle. One problem is that we seem to have a dual-process system of moral judgment, as in so much of person perception and social attribution- our "hot" moral intuitions usually precede "cool" moral reasoning (Haidt 2001). These hot moral judgments are often driven by morally judgmental emotions that figure prominently in sexual relationships, such as anger (Ellis and Malamuth 2000), disgust (Rozin et al. 1999), jealousy (Buss 2000), embarrassment (Keltner and Buswell 1997), shame (Tangney 1999), and gratitude (McCullough et al. 2001). Our moral judgments may also arise from implicit social attitudes that may be difficult to consciously articulate into normative-ethical principles (see Greenwald et al. 2002).

Second, if our person-perception system relies on social inference heuristics that are fast, frugal, and pragmatic, then our moral judgments will often violate procedural norms of rationality derived from logic, statistics, and rational choice theory, such as consistency, transitivity, and completeness (Gigerenzer and Todd 1999). There are deep decisiontheoretic reasons why it may be impossible to derive a set of consistent, coherent moral preferences from the operation of such social-inference heuristics. To know whether this is a fatal objection to the reflective equilibrium approach, we need to learn a lot more about moral judgment heuristics in the context of person-perception research (e.g., Funder 2004; Haselton and Nettle 2006).

Third, human moral intuitions evolved to assess people's stable moral virtues in ancestrally typical, fitness relevant situations, and to guide ancestrally feasible forms of social response, such as forming friendships or mateships, gossiping about liars, punishing cheaters, or ostracizing psychopaths. There is no reason to expect our moral intuitions to show consistent, logically defensible reactions to evolutionarily novel moral dilemmas that involve isolated, hypothetical, behavioral acts by unknown strangers who cannot be rewarded or punished through any normal social primate channels.

For example, we often seem cognitively paralyzed by many current debates in reproductive bioethics (Petrinovich 1995). How should we feel about abortion, sperm and egg donation, surrogate pregnancy, human cloning, genetic testing, or genetic enhancement? Different framings of these issues will activate different domain-specific moral intuitions (Haidt 2001). This is precisely why rhetorical metaphors are effective in such moral debates. For example, genetic enhancement may seem perniciously fascist if we view it as a limited resource that will be appropriated by the powerful for their nefarious ends, or it may seem democratically liberating if we view it as a natural extension of good genes mate choice for those whose own suboptimal mate value precludes getting good genes from a willing partner (Miller 2000a). Is there any neutral, rational position from which we can judge such issues without assimilating them to one or another of our domain-specific moral intuitions? Probably not. Rational decision making depends upon subjective utility functions that must be supplied either by the genetic imitation of ancestral utilities (gut instinct), or the social imitation of peer utilities 
(learning, social norms). Gut moral instincts will be mute or misleading guides to moral dilemmas raised by new technology, and moral conformity to peer opinion will be biased by vested political, corporate, and media interests that define the current ethical issues in their own interests.

Basically, there is no compelling reason to think that our moral intuitions have any true normative credibility as guides to genuinely moral behavior. Of course, there may be evolutionary reasons to expect that species-typical human moral intuitions would tend to maximize inclusive fitness under ancestral conditions. However, that is quite different from claiming that they are normatively justifiable in any broader sense. For example, Peter Singer (1995) has made some compelling but counterintuitive arguments concerning animal rights, euthanasia, and infanticide; in such cases, it seems impossible to reach a reflective equilibrium between our gut moral instincts and our scientifically informed normative judgments.

This is not to say that rationally adjudicated principles of normative ethics are impossible to achieve-only that most humans are likely to find such principles emotionally uncompelling and cognitively incomprehensible. The analogy to higher mathematics may be instructive. Humans did not evolve cognitive capacities for manipulating abstract symbol systems to prove difficult mathematical theorems. Only a tiny minority of humans with extraordinarily high intelligence can do so, given years of rigorous training. When Terence Tao was awarded the 2006 Fields Medal in mathematics for his contributions to partial differential equations, combinatorics, harmonic analysis, and additive number theory, the popular science press could not hope to convey the substance of his contributions to these areas. They could only hint at the magnitude of his genius, by mentioning that Tao was promoted to full professor at UCLA at age 24 . Of course, there are a few thousand mathematicians in the world who can understand Tao's work and reach a consensus about its creativity, but to ordinary people, good harmonic analysis work is indistinguishable from bad harmonic analysis work. Normative ethics seems likely, at best, to become a dis- cipline like higher mathematics-a small world of like-minded geniuses pursuing consensual moral truths that remain forever beyond the moral imaginations of most humans.

In light of these problems, consider two different forms of a typical normative-ethics question. Abstract form: Is it morally right to assassinate a genocidal war criminal? (Perhaps; many have praised the attempted assassination of Adolf Hitler by Colonel Claus von Stauffenberg on July 20, 1944). Personal form: Suppose there is a 21st century head of state, who ordered his country into a fraudulent and illegal war that resulted in thousands of needless civilian casualties, but who is almost certain to avoid accountability to the International Criminal Court in The Hague. Is it morally right for a woman to feel sexually attracted to a man who succeeded in killing the wicked head of state with a single head shot from a Barrett M82A1 .50-caliber sniper rifle at 800 meters on a windy day? The personal form is much more specific about the identities of the moral judgment maker, the morally-judged individual, the civilian victims, the nature of the assassination, and the fitness relevant, sociosexual implications of the moral judgment. These details should (and do) matter in making adaptive matechoice judgments about the moral virtues of snipers. A woman who knows her ordnance might admire the sniper's good genes indicators, such as his resourcefulness (the M82A1 costs $\$ 7,775$ retail), his physical condition (the 13 kilogram, $145 \mathrm{~cm}$-long rifle is hard to carry), and his marksmanship (the 800 meter head shot was near the rifle's maximum effective antipersonnel range of 1000 meters). Yet, she may equally worry about his good parent indicators: his vigilante action may reveal psychopathy, paranoid schizophrenia, bipolar disorder, impulsiveness, fame-seeking narcissism, or high risk sensation seeking (Meloy et al. 2004). She can only tell by gathering further information about his virtues, both moral and nonmoral, which is a central function of prolonged human courtship.

\section{ACKNOWLEDGMENTS}

For helpful feedback on these ideas, thanks to Paul Andrews, Rosalind Arden, Joseph Bilbulia, James 
Boone, Oliver Curry, Dylan Evans, Steve Gangestad, Walter Sinnott-Armstrong, Peter Todd, and an anon- ymous reviewer. Special thanks to Lars Penke for excellent suggestions on shortening this paper.

\section{REFERENCES}

Alvard M, Gillespie A. 2004. Good Lamalera whale hunters accrue reproductive benefits: reevaluating the hunting hypothesis. Research in Economic An $\rightarrow$ thropology 23:225-247.

$\rightarrow$ Alvard M S, Nolin D A. 2002. Rousseau's whale hunt? Coordination among big-game hunters. Curren. $\rightarrow$ Bo Anthropology 43:533-559.

$\rightarrow$ Andersson M, Simmons L W. 2006. Sexual selection and mate choice. Trends in Ecology and Evolution 21:296-302.

Andrews P W, Gangestad S W, Matthews D. 2002. Adaptationism: how to carry out an exaptationist program. Behavioral and Brain Sciences 25:489-553.

$\rightarrow$ Archer J, Mehdikhani M. 2003. Variability among males in sexually selected attributes. Review of General Psychology 7:219-236.

$\rightarrow$ Asendorpf J B, Wilpers S. 1998. Personality effects on social relationships. Journal of Personality and Social Psychology 74:1531-1544.

Axtell G, editor. 2000. Knowledge, Belief, and Character. Readings in Virtue Epistemology. Lanham (MD): Rowman and Littlefield Publishers.

$\rightarrow$ Barclay P. 2004. Trustworthiness and competitive altruism can also solve the "tragedy of the commons." Evolution and Human Behavior 25:209-220.

$\rightarrow$ Baron-Cohen S. 2002. The extreme male brain theor: of autism. Trends in Cognitive Sciences 6:248-254.

$\rightarrow$ Barriga A Q, Morrison E M, Liau A K, Gibbs J C. 2001. Moral cognition: explaining the gender difference $\rightarrow$ in antisocial behavior. Merrill-Palmer Quarterly 47: 532-562.

$\rightarrow$ Baumeister R F, Catanese K R, Wallace H M. 2002 Conquest by force: a narcissistic reactance theory of rape and sexual coercion. Review of General Psychology 6:92-135.

$\rightarrow$ Berry D S, Miller K M. 2001. When boy meets girl: attractiveness and the five-factor model in oppo site-sex interactions. Journal of Research in Personality 35:62-77.

$\rightarrow$ Betzig L. 1989. Causes of conjugal dissolution: a crosscultural study. Current Anthropology 30:654-676.

$\rightarrow$ Bleske A L, Shackelford T K. 2001. Poaching, promis cuity, and deceit: combatting mating rivalry in same-sex friendships. Personal Relationships 8:407424.

$\rightarrow$ Bogg T, Roberts B W. 2004. Conscientiousness and health-related behaviors: a meta-analysis of the leading behavioral contributors to mortality. $P$ s) $\rightarrow$ chological Bulletin 130:887-919.

$\rightarrow$ Boon S D, McLeod B A. 2001. Deception in romantic relationships: subjective estimates of success at de ceiving and attitudes toward deception. Journal of Social and Personal Relationships 18:463-476.

Boone J L. 1998. The evolution of magnanimity: when is it better to give than to receive? Human Nature 9:1-21.

Botwin M D, Buss D M, Shackelford T K. 1997. Personality and mate preferences: five factors in mate selection and marital satisfaction. Journal of Personality 65:107-136.

Boyd R, Gintis H, Bowles S, Richerson P. 2003. The evolution of altruistic punishment. Proceedings of the National Academy of Sciences USA 100:3531-3535.

Boyd R, Richerson P J. 1990. Group selection among alternative evolutionarily stable strategies. Journal of Theoretical Biology 145:331-342.

Boyer P. 2001. Religion Explained: The Evolutionary Origins of Religious Thought. New York: Basic Books.

Bradbury J W, Vehrencamp S L. 1998. Principles of Animal Communication. Sunderland (MA): Sinauer Associates.

Bradbury T N, Fincham F D, Beach S R H. 2000. Research on the nature and determinants of marital satisfaction: a decade in review. Journal of Marriage and the Family 62:964-980.

Brady M, Pritchard D, editors. 2003. Moral and Epistemic Virtues. Malden (MA): Blackwell Publishing.

Brandt H, Sigmund K. 2005. Indirect reciprocity, image scoring, and moral hazard. Proceedings of the $\mathrm{Na}$ tional Academy of Sciences USA 102:2666-2670.

Brase G L. 2006. Cues of parental investment as a factor in attractiveness. Evolution and Human Behavior 27:145-157.

Brosnan S F, de Waal F B M. 2003. Monkeys reject unequal pay. Nature 425:297-299.

Burmann C G, Pelaez F, Sanchez S. 2002. Elección de pareja estable a través de amimcops de periódico. Psicothema 14:268-273.

Buss D M. 1989. Sex differences in human mate selection: evolutionary hypotheses tested in 37 cultures. Behavioral and Brain Sciences 12:1-49.

Buss D M. 2000. The Dangerous Passion: Why Jealousy Is as Necessary as Love and Sex. New York: Free Press.

Buss D M, Schmitt D P. 1993. Sexual strategies theory: an evolutionary perspective on human mating. Psychological Review 100:204-232.

Buss D M, Shackelford T K. 1997. Susceptibility to infidelity in the first year of marriage. Journal of Research in Personality 31:193-221.

Butler J C. 2000. Personality and emotional correlates of right-wing authoritarianism. Social Behavior and Personality 28:1-14.

Byrne M, Agerbo E, Ewald H, Eaton W W, Mortensen 
P B. 2003. Parental age and risk of schizophrenia: a case-control study. Archives of General Psychiatry 60:673-678.

$\rightarrow$ Byrnes J P, Miller D C, Schafer W D. 1999. Gender differences in risk taking: a meta-analysis. Psychological Bulletin 125:367-383.

Campbell A. 1999. Staying alive: evolution, culture, and women's intrasexual aggression. Behavioral and Brain Sciences 22:203-252.

Carroll J B. 1993. Human Cognitive Abilities: A Survey of Factor-Analytic Studies. Cambridge: Cambridge University Press.

$\rightarrow$ Chagnon N A. 1988. Life histories, blood revenge, and warfare in a tribal population. Science 239:985-992.

$\rightarrow$ Cherkas L F, Oelsner E C, Mak Y T, Valdes A, Spector T D. 2004. Genetic influences on female infidelity and number of sexual partners in humans: a linkage and association study of the role of the vasopressin receptor gene (AVPR1A). Twin Researcn 7:649-658.

Code L. 1987. Epistemic Responsibility. Hanover (NH): University Press of New England.

$\rightarrow$ Coid J W. 2003. The co-morbidity of personality dis order and lifetime clinical syndromes in dangerous offenders. Journal of Forensic Psychiatry and Psychology 14:341-366.

Costa P T, Jr, McCrae R R. 1992. Revised NEO Personality Inventory (NEO PI-R) and NEO Five-Factor Inventor (NEO-FFI). Odessa (FL): Psychological Assessment Resources.

$\rightarrow$ Crespi B J. 2004. Vicious circles: positive feedback in major evolutionary and ecological transitions. Trends in Ecology and Evolution 19:627-633.

$\rightarrow$ Crisp A H, Gelder M G, Rix S, Meltzer H I, Rowlands O J. 2000. Stigmatisation of people with mental illnesses. British Journal of Psychiatry 177:4-7.

$\rightarrow$ Crow J F. 2000. The origins, patterns and implication of human spontaneous mutation. Nature Reviews Genetics 1:40-47.

$\rightarrow$ Damasio H, Grabowski T, Frank R, Galaburda A M Damasio A R. 1994. The return of Phineas Gage: clues about the brain from the skull of a famou patient. Science 264:1102-1105.

Daniels N. 1996. Justice and Justification: Reflective Equi $\rightarrow$ librium in Theory and Practice. Cambridge: Cambridge University Press.

Darwin C. 1871. The Descent of Man, and Selection is Relation to Sex. London: John Murray. [Reprint. 1981. Princeton (NJ): Princeton University Press.]

$\rightarrow$ Davis M H, Luce C, Kraus S J. 1994. The heritability of characteristics associated with dispositional empathy. Journal of Personality 62:369-391.

de Waal F B M. 1997. Good Natured: The Origins of Right and Wrong in Humans and Other Animals. Cambridge (MA): Harvard University Press.

Deary I J. 2000. Looking Down on Human Intelligence:
From Psychometrics to the Brain. Oxford: Oxford University Press.

Dennett D C. 2003. Freedom Evolves. New York: Viking.

DePaul M, Zagzebski L, editors. 2003. Intellectual Virtue: Perspectives from Ethics and Epistemology. Oxford: Clarendon Press.

Dollinger S J, Leong F T L, Ulicni S K. 1996. On traits and values: with special reference to openness to experience. Journal of Research in Personality 30:2341 .

Donnellan M B, Conger R D, Bryant C M. 2004. The Big Five and enduring marriages. Journal of Research in Personality 38:481-504.

Doris J M. 1998. Persons, situations, and virtue ethics. Noûs 32:504-530.

Dreznick M T. 2003. Heterosocial competence of rapists and child molesters: a meta-analysis. Journal of Sex Research 40:170-178.

Dunsieth N W, Nelson E B, Brusman-Lovins L A, Holcomb J L, Beckman D, Welge J A, Roby D, Taylor P, Jr, Soutullo C A, McElroy S L. 2004. Psychiatric and legal features of 113 men convicted of sexual offenses. Journal of Clinical Psychiatry 65:293-300.

Eagly A H, Ashmore R D, Makhijani M G, Longo L C. 1991. What is beautiful is good, but . . . : a metaanalytic review of research on the physical attractiveness stereotype. Psychological Bulletin 110:109128.

Ellis B J, Malamuth N M. 2000. Love and anger in romantic relationships: a discrete systems model. Journal of Personality 68:525-556.

Ellis L. 2001. The biosocial female choice theory of social stratification. Social Biology 48:298-320.

Engel G, Olson K R, Patrick C. 2002. The personality of love: fundamental motives and traits related to components of love. Personality and Individual Differences 32:839-853.

Farthing G W. 2005. Attitudes toward heroic and nonheroic physical risk takers as mates and as friends. Evolution and Human Behavior 26:171-185.

Fehr E, Fischbacher U. 2004. Social norms and human cooperation. Trends in Cognitive Sciences 8:185-190.

Fehr E, Gächter S. 2002. Altruistic punishment in humans. Nature 415:137-140.

Fincham F D, Beach S R H, Davila J. 2004. Forgiveness and conflict resolution in marriage. Journal of Family Psychology 18:72-81.

Fink B, Penton-Voak I. 2002. Evolutionary psychology of facial attractiveness. Current Directions in Psychological Science 11:154-158.

Flanagan O. 1991. Varieties of Moral Personality: Ethics and Psychological Realism. Cambridge (MA): Harvard University Press

Frank R H. 1988. Passions within Reason: The Strategic Role of the Emotions. New York: W. W. Norton.

Funder D C. 2004. The Personality Puzzle. Third Edition. New York: W. W. Norton. 
$\rightarrow$ Gangestad S W, Simpson J A. 2000. The evolution of human mating: trade-offs and strategic pluralism. Behavioral and Brain Sciences 23:573-644.

$\rightarrow$ Gangestad S W, Simpson J A, Cousins A J, Garver $\rightarrow$ Apgar C E, Christensen P N. 2004. Women's preferences for male behavioral displays change across the menstrual cycle. Psychological Science 15:203207.

$\rightarrow$ Geary D C. 2000. Evolution and proximate expression of human paternal investment. Psychological Bull $\rightarrow \mathrm{H}$ tin 126:55-77.

$\rightarrow$ Getty T. 2006. Sexually selected signals are not similar to sports handicaps. Trends in Ecology and Evolution 21:83-88.

Gigerenzer G, Todd P M, ABC Research Group, editors. 1999. Simple Heuristics that Make Us Smart. New York: Oxford University.

$\rightarrow$ Gintis H, Smith E A, Bowles S. 2001. Costly signalin and cooperation. Journal of Theoretical Biology 213:103-119.

$\rightarrow$ Goldberg T L. 1995. Altruism towards panhandlers: who gives? Human Nature 6:79-90.

$\rightarrow$ Gordon R A. 1997. Everyday life as an intelligence test: effects of intelligence and intelligence context. Intelligence 24:203-320.

$\rightarrow$ Gosling S D. 2001. From mice to men: what can wr learn about personality from animal research? Psychological Bulletin 127:45-86.

$\rightarrow$ Gottfredson L S. 1997. Why $g$ matters: the complexity of everyday life. Intelligence 24:79-132.

$\rightarrow$ Gottfredson L S. 2004. Intelligence: is it the epidemi ologists' elusive "fundamental cause" of social class inequalities in health? Journal of Personality and Social Psychology 86:174-199.

$\rightarrow$ Gottman J M, Coan J, Carrere S, Swanson C. 1998. Predicting marital happiness and stability from newlywed interactions. Journal of Marriage and tho Family 60:5-22.

$\rightarrow$ Grant B F, Hasin D S, Stinson F S, Dawson D A, Chou S P, Ruan W J, Pickering R P. 2004. Prevalence, correlates, and disability of personality disorders in the United States: results from the National Epidemiologic Survey on Alcohol and Related Conditions. Journal of Clinical Psychiatry 65:948-958.

$\rightarrow$ Graziano W G, Jensen-Campbell L A, Hair E C. 1996 Perceiving interpersonal conflict and reacting to it: the case for agreeableness. Journal of Personality and Social Psychology 70:820-835.

$\rightarrow$ Greenwald A G, Banaji M R, Rudman L A, Farnham S D, Nosek B A, Mellott D S. 2002. A unified theor, of implicit attitudes, stereotypes, self-esteem, and self-concept. Psychological Review 109:3-25.

Griskevicius V, Cialdini R B, Kenrick D T. 2006. Peacocks, Picasso, and parental investment: the effect of romantic motives on creativity. Journal of Personality and Social Psychology 9163-76.

$\rightarrow$ Gurven M, Allen-Arave W, Hill K, Hurtado M. 2000.
"It's a wonderful life:" signaling generosity among the Ache of Paraguay. Evolution and Human Behavior 21:263-282.

Haidt J. 2001. The emotional dog and its rational tail: a social intuitionist approach to moral judgment. Psychological Review 108:814-834.

Hamilton W D. 1964. The genetical theory of social behaviour. I, II. Journal of Theoretical Biology 7:1-16, 17-52.

Harman G. 1999. Moral philosophy meets social psychology: virtue ethics and the fundamental attribution error. Proceedings of the Aristotelian Society 99:315-331.

$\rightarrow$ Haselton M G, Buss D M, Oubaid V, Angleitner A. 2005. Sex, lies, and strategic interference: the psychology of deception between the sexes. Personality and Social Psychology Bulletin 31:3-23.

Haselton M G, Miller G F. 2006. Women's fertility across the cycle increases the short-term attractiveness of creative intelligence. Human Nature 17:5073.

Haselton M G, Nettle D. 2006. The paranoid optimist: an integrated evolutionary model of cognitive biases. Personality and Social Psychology Review 10:4766.

Haukka J, Suvisaari J, Lönnqvist J. 2003. Fertility of patients with schizophrenia, their siblings, and the general population: a cohort study from 1950 to 1959 in Finland. American Journal of Psychiatry 160:460-463.

Hawkes K. 1991. Showing off: tests of another hypothesis about men's foraging goals. Ethology and Sociobiology 12:29-54.

Hawkes K, Bliege Bird R. 2002. Showing off, handicap signaling, and the evolution of men's work. Evolutionary Anthropology 11:58-67.

Hawkes K, O'Connell J F, Blurton Jones N G. 2001. Hunting and nuclear families: some lessons from the Hadza about men's work. Current Anthropology 42:681-709.

Henrich J, Boyd R. 2001. Why people punish defectors: weak conformist transmission can stabilize costly enforcement of norms in cooperative dilemmas. Journal of Theoretical Biology 208:79-89.

Henrich J, Boyd R, Bowles S, Camerer C, Fehr E, Gintis H, McElreath R. 2001. In search of Homo economicus: behavioral experiments in 15 small-scale societies. American Economic Review 91:73-78.

Hofferth S L, Anderson K G. 2003. Are all dads equal? Biology versus marriage as a basis for paternal investment. Journal of Marriage and Family 65:213232.

Houle D, Kondrashov A S. 2002. Coevolution of costly mate choice and condition-dependent display of good genes. Proceedings of the Royal Society of London B 269:97-104. 
Jensen A R. 1998. The g Factor: The Science of Menta $\rightarrow$ Kokko H. 1998. Should advertising parental care be Ability. Westport (CT): Praeger.

$\rightarrow$ Jensen-Campbell L A, Graziano W G, West S G. 1995. Dominance, prosocial orientation, and femal $\rightarrow$ Kokko H, Brooks R, McNamara J M, Houston A I. preferences: do nice guys really finish last? Journal 2002. The sexual selection continuum. Proceedings of Personality and Social Psychology 68:427-440. honest? Proceedings of the Royal Society of London B 265:1871-1878.

of the Royal Society of London B 269:1331-1340.

$\rightarrow$ Johnson R C. 1996. Attributes of Carnegie medalist $\rightarrow$ Kokko H, Johnstone R A. 2002. Why is mutual mate performing acts of heroism and of the recipients choice not the norm? Operational sex ratios, sex of these acts. Ethology and Sociobiology 17:355-362.

$\rightarrow$ Jost J T, Glaser J, Kruglanski A W, Sulloway F J. 2003. Political conservatism as motivated social cognition. Psychological Bulletin 129:339-375.

$\rightarrow$ Jussim L. 2005. Accuracy in social perception: criticisms, controversies, criteria, components, and cognitive processes. Advances in Experimental Socia Psychology 37:1-93.

$\rightarrow$ Kanazawa S. 2000. Scientific discoveries as cultural displays: a further test of Miller's courtship model. Evolution and Human Behavior 21:317-321. roles and the evolution of sexually dimorphic and monomorphic signalling. Philosophical Transactions of the Royal Society of London B 357:319-330.

$\rightarrow$ Kovas Y, Plomin R. 2006. Generalist genes: implications for the cognitive sciences. Trends in Cognitive Sciences 10:198-203.

Koziel S, Pawłowski B. 2003. Comparison between primary and secondary mate markets: an analysis of data from lonely hearts columns. Personality and Individual Differences 35:1849-1857.

Keller M C, Miller G. 2006. Resolving the paradox of common, harmful, heritable mental disorders: which evolutionary genetic models work best? $B e$ havioral and Brain Sciences 29:385-452.

$\rightarrow$ Krueger R F, Hicks B M, McGue M. 2001. Altruism and antisocial behavior: independent tendencies, unique personality correlates, distinct etiologies. Psychological Science 12:397-402.

$\rightarrow$ Kelly S, Dunbar R I M. 2001. Who dares, wins: heroism versus altruism in women's mate choice. Human Nature 12:89-105.

$\rightarrow$ Keltner D, Buswell B N. 1997. Embarrassment: its distinct form and appeasement functions. Psycholog cal Bulletin 122:250-270.

Kendler K S, Gardner C O, Prescott C A. 1997. Religion, psychopathology, and substance use and abuse: a multimeasure, genetic-epidemiologic study. American Journal of Psychiatry 154:322-329.

$\rightarrow$ Kenrick D T, Sadalla E K, Groth G, Trost M R. 1990. Evolution, traits, and the stages of human courtship: qualifying the parental investment model $\rightarrow$ Journal of Personality 58:97-116.

$\rightarrow$ Kilpatrick S D, Bissonnette V L, Rusbult C E. 2002. Empathic accuracy and accommodative behavio among newly married couples. Personal Relationships 9:369-393.

$\rightarrow$ King J E, Weiss A, Farmer K H. 2005. A chimpanzee (Pan troglodytes) analogue of cross-national gener alization of personality structure: zoological parks and an African sanctuary. Journal of Personality 73:389-410.

Krueger R F, Hicks B M, Patrick C J, Carlson S R, Iacono W G, McGue M. 2002. Etiologic connections among substance dependence, antisocial behavior, and personality: modeling the externalizing spectrum. Journal of Abnormal Psychology 111:411-424.

Kuncel N R, Hezlett S A, Ones D S. 2004. Academic performance, career potential, creativity, and job performance: can one construct predict them all? Journal of Personality and Social Psychology 86:148161.

Kvanvig J L. 1992. The Intellectual Virtues and the Life of the Mind: On the Place of the Virtues in Epistemology. Savage (MD): Rowman and Littlefield Publishers.

Lacey R S, Reifman A, Scott J P, Harris S M, Fitzpatrick J. 2004. Sexual-moral attitudes, love styles, and mate selection. Journal of Sex Research 41:121-128.

Lahti D C, Weinstein B S. 2005. The better angels of our nature: group stability and the evolution of moral tension. Evolution and Human Behavior 26: 47-63.

Langlois J H, Kalakanis L, Rubenstein A J, Larson A, Hallam M, Smoot M. 2000. Maxims or myths of beauty? A meta-analytic and theoretical review. Psychological Bulletin 126:390-423.

$\rightarrow$ Kochanska G, Friesenborg A E, Lange L A, Martel M M. 2004. Parents' personality and infants' temperament as contributors to their emerging relation ship. Journal of Personality and Social Psychology 86:744-759.

$\rightarrow$ Koenigsberg H W, Harvey P D, Mitropoulou V, Schmeidler J, New A S, Goodman M, Silverman , M, Serby M, Schopick F, Siever L J. 2002. Characterizing affective instability in borderline personality disorder. American Journal of Psychiatry 159: $784-788$.

Lerner M J. 1980. The Belief in a Just World: A Fundamental Delusion. New York: Plenum Press.

Li N P, Kenrick D T, Bailey J M, Linsenmeier J A W. 2002. The necessities and luxuries of mate preferences: testing the tradeoffs. Journal of Personality and Social Psychology 82:947-955.

Loyau A, Saint Jalme M, Cagniant C, Sorci G. 2005. Multiple sexual advertisements honestly reflect health status in peacocks (Pavo cristatus). Behavioral Ecology and Sociobiology 58:552-557.

Lubinski D, Humphreys L G. 1997. Incorporating gen- 
eral intelligence into epidemiology and the socia $\rightarrow$ Metcalfe J, Mischel W. 1999. A hot/cool-system analsciences. Intelligence 24:159-201.

$\rightarrow$ Lyons M J, Koenen K C, Buchting F, Meyer J M, Eaves L, Toomey R, Eisen S A, Goldberg J, Faraone S V, ysis of delay of gratification: dynamics of willpower. Psychological Review 106:3-19.

Ban R J, Jerskey B A, Tsuang M T. 2004. A twin

Milinski M, Semmann D, Krambeck H-J. 2002. Repustudy of sexual behavior in men. Archives of Sexual Behavior 33:129-136.

$\rightarrow$ Malaspina D, Corcoran C, Fahim C, Berman A, Harkavy-Friedman J, Yale S, Goetz D, Goetz R, Harlap S, Gorman J. 2002. Paternal age and sporadic schizophrenia: evidence for de novo mutations. American Journal of Medical Genetics 114:299-303.

$\rightarrow$ Marks M J, Fraley R C. 2005. The sexual double standard: fact or fiction? Sex Roles 52:175-186.

$\rightarrow$ Matsubara M. 2003. Costs of mate guarding and opportunistic mating among wild male Japanese macaques. International Journal of Primatology 24:10571075.

Matthews G, Deary I J, Whiteman M C. 2003. Personality Traits. Second Edition. Cambridge: Cambridge University Press.

$\rightarrow$ McAndrew F T. 2002. New evolutionary perspectives on altruism: multilevel-selection and costly-signaling theories. Current Directions in Psychological Science 11:79-82.

$\rightarrow$ McCrae R R. 1996. Social consequences of experiential openness. Psychological Bulletin 120:323-337.

$\rightarrow$ McCrae R R, Costa P T, Jr, de Lima M P, Simões A, Ostendorf F, Angleitner A, Marušić I, Bratko D, Caprara G V, Barbaranelli C, Chae J-H, Piedmon R L. 1999. Age differences in personality across the adult life span: parallels in five cultures. Developmental Psychology 35:466-477.

$\rightarrow$ McCrae R R, Costa P T, Jr, Ostendorf F, Angleitner A, Hřebíčková M, Avia M D, Sanz J, Sánchez-Bernardos M L, Kusdil M E, Woodfield R, Saunders P R, Smith P B. 2000. Nature over nurture: temperament, personality, and life span development. Journal of Personality and Social Psychology 78:173-186.

$\rightarrow$ McCullough M E, Kilpatrick S D, Emmons R A, Larson D B. 2001. Is gratitude a moral affect? Psychological Bulletin 127:249-266.

$\rightarrow$ McGuire M T, Fawzy F I, Spar J E, Weigel R M, Troisi A. 1994. Altruism and mental disorders. Etholog, and Sociobiology 15:299-321.

$\rightarrow$ McKelvie S J, Coley J. 1993. Effects of crime seriousness and offender facial attractiveness on recom mended treatment. Social Behavior and Personality 21:265-277.

$\rightarrow$ Meloy J R, James D V, Farnham F R, Mullen P E, Pathe M, Darnley B, Preston L. 2004. A research review of public figure threats, approaches, attacks, and assassinations in the United States. Journal of Foren $\rightarrow$ sic Sciences 49:1086-1093.

$\rightarrow$ Merritt M. 2000. Virtue ethics and situationist personality psychology. Ethical Theory and Moral Practice 3:365-383. tation helps solve the 'tragedy of the commons.' Nature 415:424-426.

Miller G F. 1999. Sexual selection for cultural displays. Pages 71-91 in The Evolution of Culture: An Interdisciplinary View, edited by R Dunbar, C Knight, and C Power. Edinburgh: Edinburgh University Press.

Miller G F. 2000a. The Mating Mind: How Sexual Choice Shaped the Evolution of Human Nature. New York: Doubleday.

Miller G F. 2000b. Mental traits as fitness indicators: expanding evolutionary psychology's adaptationism. Pages 62-74 in Evolutionary Perspectives on Human Reproductive Behavior (Annals of the New York Academy of Sciences, Volume 907), edited by D LeCroy and P Moller. New York: New York Academy of Sciences.

Miller G F. 2000c. Sexual selection for indicators of intelligence. Pages 260-275 in The Nature of Intelligence (Novartis Foundation Symposium 233), edited by G R Bock, J A Goode, and K Webb. New York: Wiley.

Miller G F. 2001. Aesthetic fitness: how sexual selection shaped artistic virtuosity as a fitness indicator and aesthetic preferences as mate choice criteria. Bulletin of Psychology and the Arts 2:20-25.

Miller G F, Penke L. 2007. The evolution of human intelligence and the coefficient of additive genetic variance in human brain size. Intelligence 35:97114.

Miller G F, Todd P M. 1995. The role of mate choice in biocomputation: sexual selection as a process of search, optimization, and diversification. Pages 169-204 in Evolution and Biocomputation: Computational Models of Evolution, edited by W Banzhaf et al. Berlin: Springer-Verlag.

Mischel W. 1968. Personality and Assessment. New York: Wiley.

Mock D W, Parker G A. 1997. The Evolution of Sibling Rivalry. Oxford: Oxford University Press.

Møller A P, Alatalo R V. 1999. Good-genes effects in sexual selection. Proceedings of the Royal Society of London B 266:85-91.

Møller A P, Petrie M. 2002. Condition dependence, multiple sexual signals, and immunocompetence in peacocks. Behavioral Ecology 13:248-253.

Montmarquet J A. 1993. Epistemic Virtue and Doxastic Responsibility. Lanham (MD): Rowman and Littlefield Publishers.

Mount M K, Barrick M R, Stewart G L. 1998. Fivefactor model of personality and performance in jobs involving interpersonal interactions. Human Performance 11:145-165.

Nakamura M, Iwasa Y. 2005. The evolution of altru- 
ism by costly punishment in lattice-structured populations: score-dependent viability versus scoredependent fertility. Evolutionary Ecology Research 7. 853-870.

$\rightarrow$ Neisser U, Boodoo G, Bouchard T J, Jr, Boykin A W, Brody N, Ceci S J, Halpern D F, Loehlin J C, Perloff R, Sternberg R J, Urbina S. 1996. Intelligence: knowns and unknowns. American Psychologist 51: $77-101$.

$\rightarrow$ Nesse R M. 2000. Is depression an adaptation? Archives of General Psychiatry 57:14-20.

Nesse R M, editor. 2001. Evolution and the Capacity for Commitment. New York: Russell Sage Foundation.

Nietzsche F. 1887. Zur Genealogie der Moral: Eine Streitschrift. Leipzig (Germany): G Navmann. [Translated and edited by M Clark and A Swensen as $O n$ the Genealogy of Morals. 1998. Indianapolis (IN): Hackett.]

$\rightarrow$ Noftle E E, Shaver P R. 2006. Attachment dimensions and the big five personality traits: associations and comparative ability to predict relationship quality. Journal of Research in Personality 40:179-208.

$\rightarrow$ Norman M D, Finn J, Tregenza T. 1999. Female impersonation as an alternative reproductive strategy in giant cuttlefish. Proceedings of the Royal Society of London B 266:1347-1349.

$\rightarrow$ Nowak M A, Sigmund K. 1998. Evolution of indirec reciprocity by image scoring. Nature 393:573-577.

$\rightarrow$ Oda R. 2001. Sexually dimorphic mate preference in Japan: an analysis of lonely hearts advertisements. Human Nature 12:191-206.

$\rightarrow$ Oliver M B, Sedikides C. 1992. Effects of sexual permissiveness on desirability of partner as a function of low and high commitment to relationship. Socia Psychology Quarterly 55:321-333.

$\rightarrow$ Organ D W, Ryan K. 1995. A meta-analytic review of attitudinal and dispositional predictors of organi zational citizenship behavior. Personnel Psychology 48:775-802.

$\rightarrow$ Ozer D J, Benet-Martínez V. 2006. Personality and thı $\rightarrow$ prediction of consequential outcomes. Annual Review of Psychology 57:401-421.

$\rightarrow$ Paunonen S V. 2006. You are honest, therefore I like you and find you attractive. Journal of Research in Personality 40:237-249.

Petrinovich L. 1995. Human Evolution, Reproduction, and Morality. New York: Plenum Press.

Pinker S. 2002. The Blank Slate: The Modern Denial of Human Nature. New York: Viking.

Plomin R, DeFries J C, McClearn G E, McGuffin F $\rightarrow$ 2001. Behavioral Genetics. Fourth Edition. New York: Worth Publishers.

$\rightarrow$ Plomin R, Spinath F M. 2002. Genetics and general cognitive ability $(g)$. Trends in Cognitive Sciences 6: 169-176.

Preston S D, de Waal F B M. 2002. Empathy: its ulti- mate and proximate bases. Behavioral and Brain Sciences 25:1-20.

Prokosch M D, Yeo R, Miller G F. 2005. Intelligence tests with higher $g$-loadings show higher correlations with body symmetry: evidence for a general fitness factor mediated by developmental stability. Intelligence 33:203-213.

Radcliffe Richards J. 2000. Human Nature after Darwin: A Philosophical Introduction. London: Routledge.

Reichenberg A, Gross R, Weiser M, Bresnahan M, Silverman J, Harlap S, Rabinowitz J, Shulman C, Malaspina D, Lubin G, Knobler H Y, Davidson M, Susser E. 2006. Advancing paternal age and autism. Archives of General Psychiatry 63:1026-1032.

Rhee S H, Waldman I D. 2002. Genetic and environmental influences on antisocial behavior: a metaanalysis of twin and adoption studies. Psychological Bulletin 128:490-529.

Ridley M. 1996. The Origins of Virtue. New York: Viking.

Ridley M. 2001. The Cooperative Gene: How Mendel's Demon Explains the Evolution of Complex Beings. New York: Free Press.

Roberts B W, Chernyshenko O S, Stark S, Goldberg L R. 2005. The structure of conscientiousness: an empirical investigation based on seven major personality questionnaires. Personnel Psychology 58:103139.

Roberts B W, DelVecchio W F. 2000. The rank-order consistency of personality traits from childhood to old age: a quantitative review of longitudinal studies. Psychological Bulletin 126:3-25.

$\rightarrow$ Roberts G. 1998. Competitive altruism: from reciprocity to the handicap principle. Proceedings of the Royal Society of London B 265:427-431.

Robins R W, Beer J S. 2001. Positive illusions about the self: short-term benefits and long-term costs. Journal of Personality and Social Psychology 80:340-352.

Roccas S, Sagiv L, Schwartz S H, Knafo A. 2002. The big five personality factors and personal values. Personality and Social Psychology Bulletin 28:789-801.

Roes F L, Raymond M. 2003. Belief in moralizing gods. Evolution and Human Behavior 24:126-135.

$\rightarrow$ Rowe L, Houle D. 1996. The lek paradox and the capture of genetic variance by condition dependent traits. Proceedings of the Royal Society of London B 263: 1415-1421.

Rozin P, Haidt J, McCauley C R. 1999. Disgust: the body and soul emotion. Pages 429-445 in Handbook of Cognition and Emotion, edited by T Dalgleish and M Power. New York: John Wiley \& Sons.

Rucas S L, Gurven M, Kaplan H, Winking J, Gangestad S, Crespo M. 2006. Female intrasexual competition and reputational effects on attractiveness among the Tsimane of Bolivia. Evolution and Human Behavior 27:40-52.

Rushton J P. 2004. Genetic and environmental contributions to prosocial attitudes: a twin study of social 
responsibility. Proceedings of the Royal Society of Lon $\rightarrow$ Skodol A E, Gunderson J G, McGlashan T H, Dyck I don $B$ 271:2583-2585.

Ryan M J. 1998. Sexual selection, receiver biases, and the evolution of sex differences. Science 281:19992003.

$\rightarrow$ Sabini J, Siepmann M, Stein J. 2001. The really fundamental attribution error in social psychological research. Psychological Inquiry 12:1-15.

R, Stout R L, Bender D S, Grilo C M, Shea M T, Zanarini M C, Morey L C, Sanislow C A, Oldham J M. 2002a. Functional impairment in patients with schizotypal, borderline, avoidant, or obsessivecompulsive personality disorder. American Journal of Psychiatry 159:276-283.

$\rightarrow$ Sackett P R, Wanek J E. 1996. New developments in the use of measures of honesty, integrity, conscientiousness, dependability, trustworthiness, and reliability for personnel selection. Personnel Ps) chology 49:787-829.

$\rightarrow$ Saulsman L M, Page A C. 2004. The five-factor model and personality disorder empirical literature: a meta-analytic review. Clinical Psychology Review 23: $1055-1085$.

$\rightarrow$ Schmitt D P. 2004a. The Big Five related to risky sexual behaviour across 10 world regions: differential per $\rightarrow$ sonality associations of sexual promiscuity and relationship infidelity. European Journal of Personality 18:301-319.

Skodol A E, Gunderson J G, Pfohl B, Widiger T A, Livesley W J, Siever L J. 2002b. The borderline diagnosis I: psychopathology, comorbidity, and personality structure. Biological Psychiatry 51:936-950.

Skoe E E A, Cumberland A, Eisenberg N, Hansen K, Perry J. 2002. The influences of sex and genderrole identity on moral cognition and prosocial personality traits. Sex Roles 46:295-309.

Sober E, Wilson D S. 1998. Unto Others: The Evolution and Psychology of Unselfish Behavior. Cambridge (MA): Harvard University Press.

Solomonson A L, Lance C E. 1997. Examination of the relationship between true halo and halo error in performance ratings. Journal of Applied Psychology 82:665-674. $\rightarrow$ Schmitt D P. 2004b. Patterns and universals of mat
poaching across 53 nations: the effects of sex, culture, and personality on romantically attracting another person's partner. Journal of Personality and $S_{c}$ cial Psychology 86:560-584.

$\rightarrow$ Schmitt D P, Buss D M. 1996. Strategic self-promotion and competitor derogation: sex and context ef fects on the perceived effectiveness of mate attraction tactics. Journal of Personality and Social Psychology 70:1185-1204.

$\rightarrow$ Schmitt D P, Couden A, Baker M. 2001. The effects of sex and temporal context on feelings of romantic desire: an experimental evaluation of sexual strat $\rightarrow$ egies theory. Personality and Social Psychology Bulletin 27:833-847.

Sosis R. 2000. Costly signaling and torch fishing on Ifaluk atoll. Evolution and Human Behavior 21:223244.

Spearman C. 1904. "General intelligence," objectively determined and measured. American Journal of Psychology 15:201-292.

Spinath F M, O'Connor T G. 2003. A behavioral genetic study of the overlap between personality and parenting. Journal of Personality 71:785-808.

Stanford C B. 1999. The Hunting Apes: Meat Eating and the Origins of Human Behavior. Princeton (NJ): Princeton University Press.

$\rightarrow$ Stohr K, Wellman C H. 2002. Recent work on virtue ethics. American Philosophical Quarterly 39:49-72.

$\rightarrow$ Schulte M J, Ree M J, Carretta T R. 2004. Emotional intelligence: not much more than $g$ and personality. Personality and Individual Differences 37:10591068.

$\rightarrow$ Sugiyama L S, Sugiyama M S. 2003. Social roles, prestige, and health risk: social niche specialization as a risk-buffering strategy. Human Nature 14:165190.

$\rightarrow$ Schutte N S, Malouff J M, Hall L E, Haggerty D J, Cooper J T, Golden C J, Dornheim L. 1998. Development and validation of a measure of emotional intelligence. Personality and Individual Differences 25:167-177.

$\rightarrow$ Seinen I, Schram A. 2006. Social status and group norms: Indirect reciprocity in a repeated helping experiment. European Economic Review 50:581-602.

$\rightarrow$ Shaner A, Miller G, Mintz J. 2004. Schizophrenia as one extreme of a sexually selected fitness indicator. Schizophrenia Research 70:101-109.

Singer P. 1995. Rethinking Life and Death: The Collapse of Our Traditional Ethics. New York: St. Martin's Press.

$\rightarrow$ Sugiyama L S, Tooby J, Cosmides L. 2002. Cross-cultural evidence of cognitive adaptations for social exchange among the Shiwiar of Ecuadorian Amazonia. Proceedings of the National Academy of Sciences USA 99:11537-11542.

Symons D. 1995. Beauty is in the adaptations of the beholder: the evolutionary psychology of human female sexual attractiveness. Pages 80-118 in Sexual Nature, Sexual Culture, edited by P R Abramson and S D Pinkerton. Chicago (IL): University of Chicago Press.

Tangney J P. 1999. The self-conscious emotions: shame, guilt, embarrassment and pride. Pages 541-568 in Handbook of Cognition and Emotion, edited by T Dalgleish and M Power. New York: John Wiley \& Sons.

Sinnott-Armstrong W. 1984. 'Ought' conversationally implies 'can.' Philosophical Review 93:249-261.

Taylor S E, Klein L C, Lewis B P, Gruenewald T L, 
Gurung R A R, Updegraff J A. 2000. Biobehaviora responses to stress in females: tend-and-befriend, not fight-or-flight. Psychological Review 107:411-429.

$\rightarrow$ Tessman I. 1995. Human altruism as a courtship display. Oikos 74:157-158.

Thornhill R, Palmer C T. 2000. A Natural History o Rape: Biological Bases of Sexual Coercion. Cambridge (MA): MIT Press.

Todd P M, Miller G F. 1999. From Pride and Prejudice to Persuasion: satisficing in mate search. Pages 287-308 in Simple Heuristics that Make Us Smart, edited by G Gigerenzer, P M Todd, and the ABC Research Group. New York: Oxford University Press

$\rightarrow$ Tomkins J L, Radwan J, Kotiaho J S, Tregenza T. 2004. Genic capture and resolving the lek paradox. Trends in Ecology and Evolution 19:323-328.

$\rightarrow$ Tooby J, Cosmides L. 1990a. The past explains the present: emotional adaptations and the structure of ancestral environments. Ethology and Sociobiolog 11:375-424.

$\rightarrow$ Tooby J, Cosmides L. 1990b. On the universality of human nature and the uniqueness of the individual: the role of genetics and adaptation. Journal of Personality 58:17-67.

$\rightarrow$ Trivers R L. 1971. The evolution of reciprocal altruism. Quarterly Review of Biology 46:35-57.

$\rightarrow$ Trivers R L. 1974. Parent-offspring conflict. American Zoologist 14:249-264.

$\rightarrow$ Urbaniak G C, Kilmann P R. 2003. Physical attractiveness and the "nice guy paradox": do nice guys really finish last? Sex Roles 49:413-426.

$\rightarrow$ Vahed K. 1998. The function of nuptial feeding in insects: a review of empirical studies. Biological Reviews $73: 43-78$.

$\rightarrow$ Van Hiel A, Mervielde I, De Fruyt F. 2004. The relationship between maladaptive personality and right wing ideology. Personality and Individual Differences 36:405-417.

Veblen T. 1899. The Theory of the Leisure Class: An Economic Study in the Evolution of Institutions. Nev $\rightarrow$ York: Macmillan. [Reprint. 1994. New York: Dover Press.]
Watson D, Hubbard B, Wiese D. 2000. General traits of personality and affectivity as predictors of satisfaction in intimate relationships: evidence from self- and partner-ratings. Journal of Personality 68: 413-449.

Watson D, Klohnen E C, Casillas A, Simms E N, Haig J, Berry D S. 2004. Match makers and deal breakers: analyses of assortative mating in newlywed couples. Journal of Personality 72:1029-1068.

Whiten A W, Byrne R W, editors. 1997. Machiavellian Intelligence II: Extensions and Evaluations. Cambridge: Cambridge University Press.

Wilson D S, Near D, Miller R R. 1996. Machiavellianism: a synthesis of the evolutionary and psychological literatures. Psychological Bulletin 119:285-299.

$\rightarrow$ Wilson M, Daly M. 2004. Do pretty women inspire men to discount the future? Proceedings of the Royal Society of London B 271 (supplement):S177-S179.

Yeo R A, Gangestad S W, Edgar C, Thoma R. 1999. The evolutionary genetic underpinnings of schizophrenia: the developmental instability model. Schizophrenia Research 39:197-206.

Zagzebski L T. 1996. Virtues of the Mind: An Inquiry into the Nature of Virtue and the Ethical Foundations of Knowledge. Cambridge: Cambridge University Press

$\rightarrow$ Zahavi A. 1975. Mate selection: a selection for a handicap. Journal of Theoretical Biology 53: 205-214.

Zahavi A, Zahavi A. 1997. The Handicap Principle: A Missing Piece of Darwin's Puzzle. New York: Oxford University Press.

$\rightarrow$ Zahn-Waxler C, Robinson J L, Emde R N. 1992. The development of empathy in twins. Developmental Psychology 28:1038-1047.

$\rightarrow$ Zammitt S, Allebeck P, David A S, Dalman C, Hemmingsson T, Lundberg I, Lewis G. 2004. A longitudinal study of premorbid IQ score and risk of developing schizophrenia, bipolar disorder, severe depression, and other nonaffective psychoses. $A r$ chives of General Psychiatry 61:354-360.

Zuckerman M, Kuhlman D M. 2000. Personality and risk-taking: common biosocial factors. Journal of Personality 68:999-1029. 
